\title{
Sarcopterygian and other Fishes from the Marine Upper Devonian of Colorado, U.S.A.
}

\author{
Hans-Peter Schultze ${ }^{1} \&$ John Chorn ${ }^{2}$
}

With 18 Figures

\begin{abstract}
The fish fauna of Upper Devonian deposits of SW Colorado is described and compared with those of Central Colorado. The osteolepidid Litoptychus is redescribed including skull roof, cheek, palatoquadrate, cleithrum and postcranial elements. A second osteolepidid with cosmine-covered scales and bones is recognized in the Upper Devonian deposits of Colorado. A skull roof and a parasphenoid formerly attributed to Litoptychus, and a pterygoid, cleithrum, ribs and scales are assigned to dipnoans, partly to long-snouted dipnoans cf. Soederberghia. Comparison of the Late Devonian fish fauna of Colorado with that of Arizona places the fishes of Colorado into a coastal marine depositional environment.
\end{abstract}

Key words: Fishes, Devonian, Colorado, Morphology, Palaeoecology

\section{Zusammenfassung}

Die oberdevonische Fischfauna von SW Colorado ist beschrieben und mit der von Zentral-Colorado verglichen. Die osteolepidide Gattung Litoptychus ist neu beschrieben einschließlich Schädeldach, Wangenregion, Palatoquadratum, Cleithrum und postkranialer Elemente und diagnostiziert. Ein zweiter Osteolepidide mit Kosmin bedeckten Schuppen und Knochen wird von Litoptychus (ohne Kosmin) abgetrennt. Ein Schädeldach und ein Parasphenoid, die früher zu Litoptychus gestellt wurden, und ein Pterygoid, ein Cleithrum, Rippen und Schuppen werden zu Lungenfischen gestellt, z. T. zu langschnauzigen Lungenfischen cf. Soederberghia. - Der Vergleich der spätdevonischen Fischfauna von Colorado mit der von Arizona deutet auf eine küstennahe marine Lebenswelt der Colorado-Fische hin.

Schlïsselwörter: Fische, Devon, Colorado, Morphologie, Paläoökologie

\section{Introduction}

Denison (1951) described Late Devonian fishes from sites in Arizona, Colorado, Utah and Wyoming. He focused on what he believed to be freshwater fishes, leaving out the clearly marine Late Devonian fishes of Arizona (see Johnson \& Elliott 1995, 1996) and New Mexico. He reviewed all earlier descriptions beginning with the earliest discoveries in southwestern Colorado (Endlich 1876, Cross 1904, Eastman 1904). Endlich discovered fossil fishes in a sandstone on the eponymous Endlich Mesa, west of Vallecito Valley. Late Devonian fishes have been collected further west of Endlich Mesa; one block with fishes was collected from talus south of Rockwood, La Plata County, Colorado. According to Denison (1951) this block must derive from an outcrop north of Rockwood on Little Cascade Creek, south of Columbine Lake. In the 1980's, Dr. Douglas Brew, Fort Lewis College, Durango, discovered a new fish locality on the plateau east of Vallecito Valley just west of Dollar Lake $(2,4 \mathrm{~km}$ west of the southern tip of Emerald Lake).

In the summer of 1993 the authors, together with Dr. Brew, hiked to the locality from the trail head north of Vallecito Reservoir at about 9000 feet above sea level. We camped near the locality and collected at 11920 feet $(3633 \mathrm{~m}$ above NN) above sea level for three days.

Colorado localities cited in this paper (Fig. 1):

A. Parting Formation, Chaffee Group, Frasnian, Upper Devonian:

1. Deadman's Gulch, Gunnison County, Central Colorado: NW1/4 sec. 23, T.14S.,

\footnotetext{
${ }^{1}$ (Corresponding address): Museum für Naturkunde, Institut für Paläontologie, Invalidenstr. 43, D-10115 Berlin, Germany.

2 Natural History Museum, The University of Kansas, Lawrence, Kansas 66045-2454, U.S.A. Received January 1998, accepted May 1998
} 


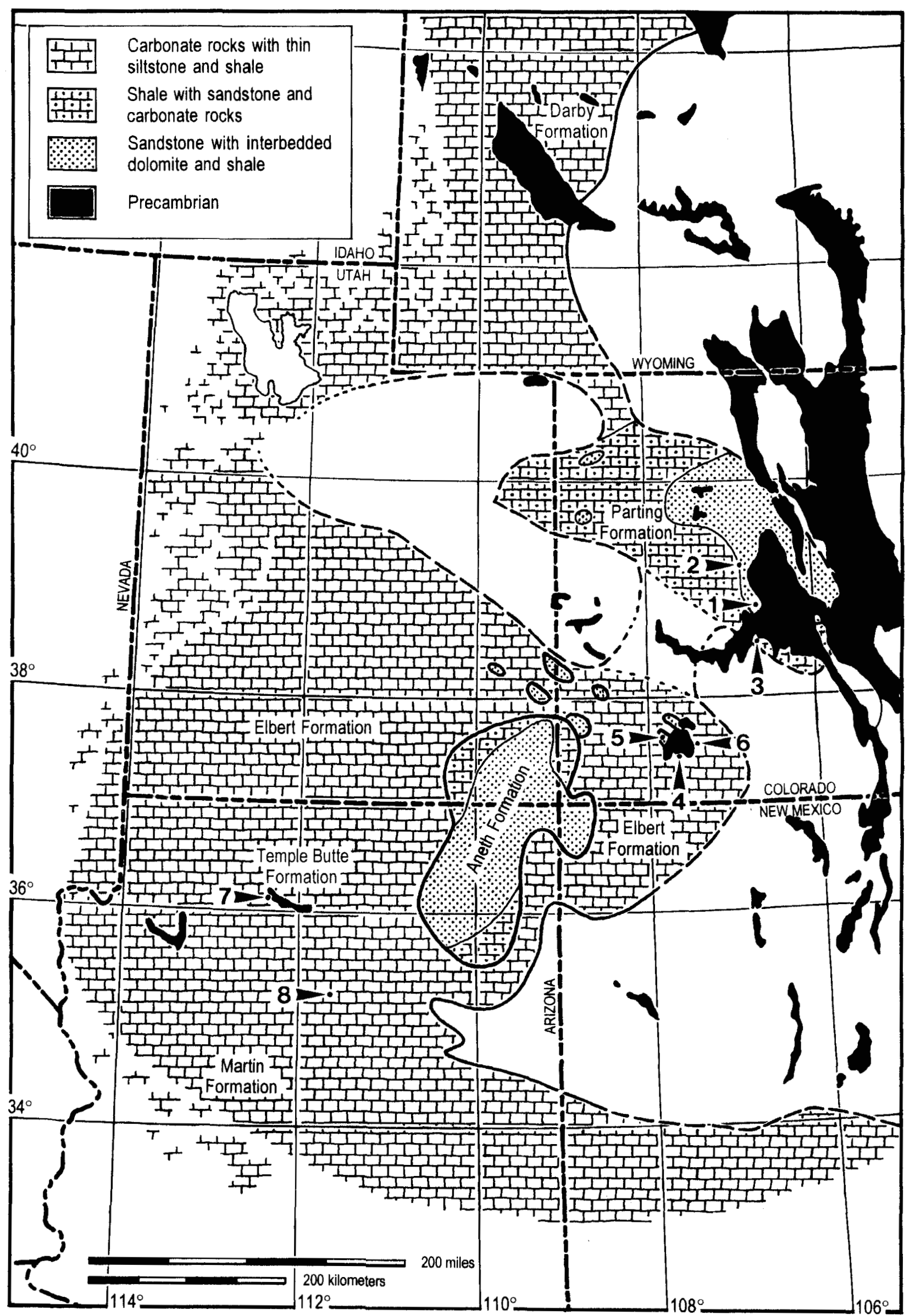


R.84W. (Taylor Park Quadrangle. $38^{\circ} 49^{\prime}$ N/ $\left.106^{\circ} 44^{\prime} 30^{\prime \prime} \mathrm{W}\right)$.

2. Spar Gulch near Aspen, Pitkin County, Central Colorado: W of sec. 18, T.10S., R.84W., to E of secs. 24 and 25, T.10S., R.85W. (Aspen Quadrangle. $39^{\circ} 10^{\prime} 48^{\prime \prime} \mathrm{N} /$ $106^{\circ} 49^{\prime} 05^{\prime \prime} \mathrm{W}$ to $39^{\circ} 09^{\prime} 44^{\prime \prime} \mathrm{N} / 106^{\circ} 49^{\prime} 20^{\prime \prime} \mathrm{W}$ ).

3. Boulder Lake at north end of Fossil Ridge, Gunnison County, Central Colorado: sec. 23, T.51N., R.3E. (Fairview Peak Quadrangle. $\left.38^{\circ} 40^{\prime} 13^{\prime \prime} \mathrm{N} / 106^{\circ} 37^{\prime} \mathrm{W}\right)$.

B. Elbert Formation, Frasnian, Upper Devonian:

4. Endlich Mesa, La Plata County, SW Colorado: sec. 1,2,11, T.37N., R.7W. (Columbine Pass Quadrangle. about $37^{\circ} 30^{\prime} 16^{\prime \prime} \mathrm{N} /$ $107^{\circ} 37^{\prime} 30^{\prime \prime} \mathrm{W}$ ).

5. Little Cascade Creek, 1/2 mi south of Columbine Lake, La Plata County, SW Colorado: sec. 36, T.39N., R.9W. (Electra Lake Quadrangle. about $37^{\circ} 36^{\prime} \mathrm{N} / 107^{\circ} 48^{\prime} \mathrm{W}$ ).

6. Brew locality, NE of Durango and NNE of Vallecito Reservoir, Hinsdale County, SW Colorado: SE1/4 NE1/4 SW1/4, sec. 24, T.38N., R.6W. (Emerald Lake Quadrangle: $11 / 2 \mathrm{mi}=2.4 \mathrm{~km} \mathrm{~W}$ of southern tip of Emerald Lake; W of Dollar Lake. $\left.37^{\circ} 32^{\prime} 30^{\prime \prime} \mathrm{N} / 107^{\circ} 28^{\prime} 22^{\prime \prime} \mathrm{W}\right)$ at $11920 \mathrm{ft}$ (3633 $\mathrm{m})$ above sea level.

\section{Material and Methods}

Late Devonian fishes occur at the Brew locality in a conglomeratic sandstone to quartzite similar to that of fish localities farther west, and in dolomitic limestones in Central Colorado. Most material is represented by whole and fragmentary isolated bones and scales. In addition, articulated osteolepidids have been found in the less conglomeratic portions of the Brew locality sequence. Articulated bothriolepids were recorded from south of Rockwood by Eastman (1904) and from Endlich Mesa by Denison (1951). Most fish remains have a similar ornamentation of coarse tuberculation, so that it is often difficult to assign single plates to larger taxonomic units. At the Brew locality bones are attached to the rock by their ornamented surface. The specimens break through the bone making them difficult to identify. The bone does not look promising for histological investigations. In bone from nearby localities Denison (1951) observed abundant fungal burrows that made it difficult to interpret histological structures (compare Denison 1951: fig. 43B with the picture of the same section by Schultze 1969: fig. 22). Therefore, in order to develop detail many bones were dissolved with $\mathrm{HCl}$ and latex casts prepared from the resulting molds. The quarzite and sandstone are a nearly pure silicate and therefore not dissolved by $\mathrm{HCl}$. The resulting molds are highly detailed. The latex casts were coated with $\mathrm{NH}_{4} \mathrm{Cl}$ to facilitate photographing, and drawing them under Wild M5 and M8 microscopes.

Institutional Abbreviations.

FMNH: Field Museum of Natural History, Chicago, Illinois; KUVP: Natural History Museum, University of Kansas, Lawrence, Kansas.

\section{Systematics}

The collection from the Brew locality comprises one or more antiarchs, arthrodires, and five sarcopterygians. Faunal content is similar to the other five localities. We will focus on the better material of the locality. Placoderms are less common and incompletely preserved; they are well described by Denison (1951) from Central and SW Colorado, and will be dealt with here only briefly.

\section{Placodermi}

\section{Antiarchi}

\section{Bothriolepis coloradensis Eastman, 1904}

\section{Material}

Endlich Mesa: Trunk shield: FMNH PF354, PF355 (= Denison 1951: fig. 39A), PF356 (right MxL), PF357 (left MxL), PF358, PF359 (impression of left MxL), PF360 (AMD), PF361, PF363 (left MxL), PF364 (left Lateral plate = Denison 1951: fig. 40D).

Little Cascade Creek: Trunk shield: FMNH PF362 $(\mathrm{PMD}=$ Denison 1951: fig. 40E), PF569 (AVL and pectoral appendage), PF570, PF571 (right MxL), PF572 (indet. plate). Brew locality: Bones: KUVP 124450, 124455, 124457, 124461, ?124481, 124489, 124491, 124511, 124528, 124536, 124542,124548 , on 124555,124556 .

The original description of Bothriolepis coloradensis by Eastman (1904) is based on material from SW Colorado (Rockwood, La Plata County). Denison (1951) reaffirmed the assignment to Bothriolepis based on the articulation in the pectoral appendages in contrast to Stensiö $(1931,1948)$, who placed the species within remigolepids. Size is not a criterion for the species; it is moderately large for the genus. The bones have a tuberculate ornamentation with tubercles more or less confluent, but not forming vermiculating ridges (Eastman 1904). Denison (1951) noted reticular ornamentation with slight or no tubercular elevations at the anatomoses of ridges. Ridged ornamentation is more pronounced in some plates. The tuberculated ornamentation of $B$. coloradensis (Denison 1951: fig. $40 \mathrm{D}, \mathrm{E}$ ) is very similar to that of B. darbiensis (Denison 1951: fig. 40A, B), but differs from the ridges of $B$. cf. coloradensis (Denison 1951: fig. 40C).

Fig. 1. Upper Devonian fish localities of Colorado and Arizona cited in the text (explanation of numbers see Introduction) and distribution of Upper Devonian sediments (based on Baars 1972: fig. 6) 


\section{Bothriolepis cf. coloradensis}

\section{Material}

Boulder Lake: Head shield: FMNH PF588 (internal side of PNu), PF591 (internal side of NU), PF595 (NU), PF596 (right half of $\mathrm{Nu}$ ). Trunk shield: FMNH PF589 (distal segment of pectoral appendage), PF590 (PMD), PF593 (pectoral appendage), PF594 (internal side of PVL). Indet. plate: FMNH PF585, PF587, PF592.

The ridges forming ornamentation in $B$. cf. coloradensis (Denison 1951: fig. 40C) differ from all specimens of B. coloradensis from Endlich Mesa, Little Cascade Creek and the Brew locality (Denison 1951: figs. 40D+E).

\section{Arthrodira}

\section{Arthrodira indet.}

\section{Material}

Brew locality: KUVP 124471, 124492.

\section{Sarcopterygii}

At the Brew locality, dipnoans, porolepiforms, osteolepiforms and possibly onychodonts are present.

\section{Dipnoi}

The presence of dipnoans at the Brew locality is evidenced by a pterygoid whereas the assignment of scales is doubtful. Tooth plates of dipnoans were described by Eastman (1915) and Denison (1951: 238) from the Elbert Formation of SW Colorado (east of Florida Valley, near or on Endlich Mesa) and by Bryant (in Bryant \& Johnson 1936) from the Chaffee Formation of Central Colorado. The parasphenoid and some of the round scales from Deadman's Gulch, Central Colorado, and a posterior skull roof from Endlich Mesa, Southwest Colorado, assigned by Denison (1951) to Litoptychus or a holoptychiid respectively, belong to lungfish.

\section{Dipnoi indet.}

\section{Material}

Deadman's Gulch: Parasphenoid with long stem: FMNH PF614 (Denison 1951: 246). Cleithrum: FMNH PF14903. Ribs: PF616 (ribs, broad fin supporting element), PF618 (rib), Round scales: FMNH PF599, PF14915 (= PF619 of Denison 1951: fig. 42A).
Spar Gulch: Small tooth plate on FMNH PF605.

E n d l i c h M e s a: Skull roof: FMNH PF582. Tooth plate: FMNH PF 583. Round scales: FMNH PF575.

B r e w I o c a l i t y: Pterygoid: KUVP 124466. Ribs: KUVP 124478. Round scales: KUVP 124454, 124522, 124535, 124567. Indet. bone: KUVP ?124977.

\section{Description}

Skull roof (Fig. 2): The impression of the internal side of a skull roof (FMNH PF582) is preserved. A long narrow B-bone is widely underlain by large I-bones so that the posterior portion of $\mathrm{B}$ appears narrower than the anterior portion on the inner side. $\mathrm{C}$ (only the posteriormost part of the left C-bone preserved) seems to be represented by a pair of bones. The J-bone is half as long as the I-bone. The $\mathrm{Y}_{2}$-bone is half the length of the I-bone. $\mathrm{Y}_{1}$ - and XK-bone are separate. The L-bone lies in front of bone J. The long B-bone is typical for long-headed dipnoans with a long snout. Bone B is narrower anteriorly in Griphognathus and widens posteriad, especially on the inner side (Schultze 1969: fig. 9). The bone arrangement of FMNH PF582 also is distinct from Griphognathus in the size relation between bones I and J (I equal with $\mathrm{J}$ in Griphognathus). In Soederberghia bone $\mathbf{I}$ is larger

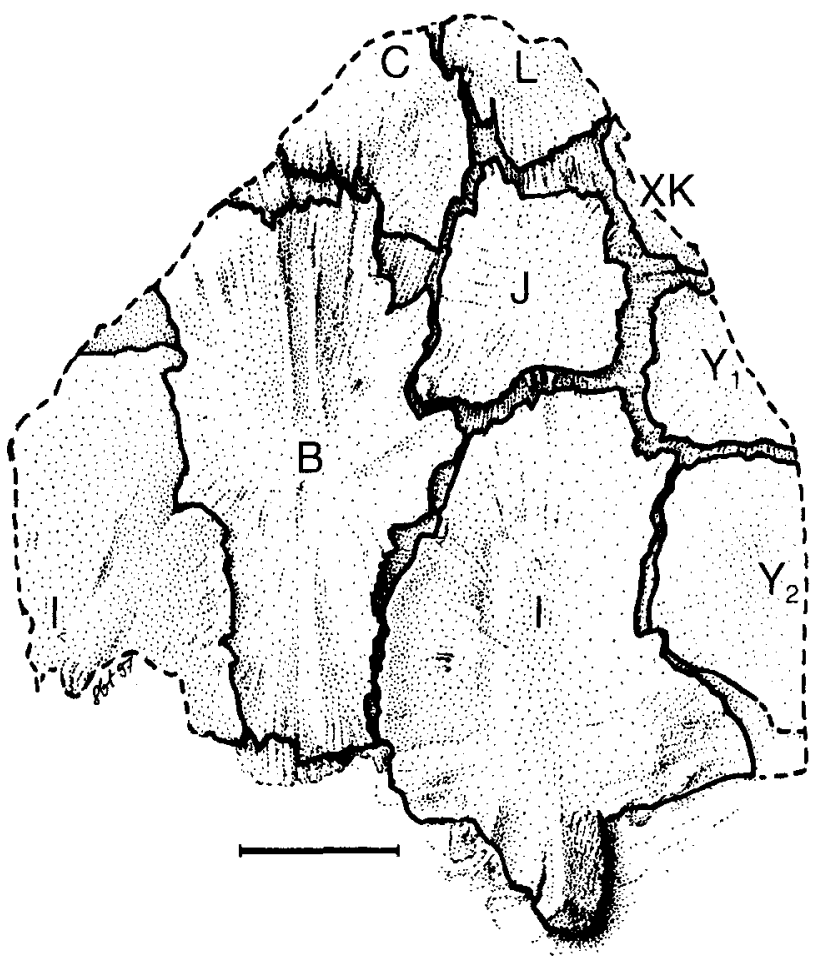

Fig. 2. Dipnoan skull roof, FMNH PF582, in ventral view. Upper Devonian, Endlich Mesa, Colorado. Scale represents $1 \mathrm{~cm}$ 


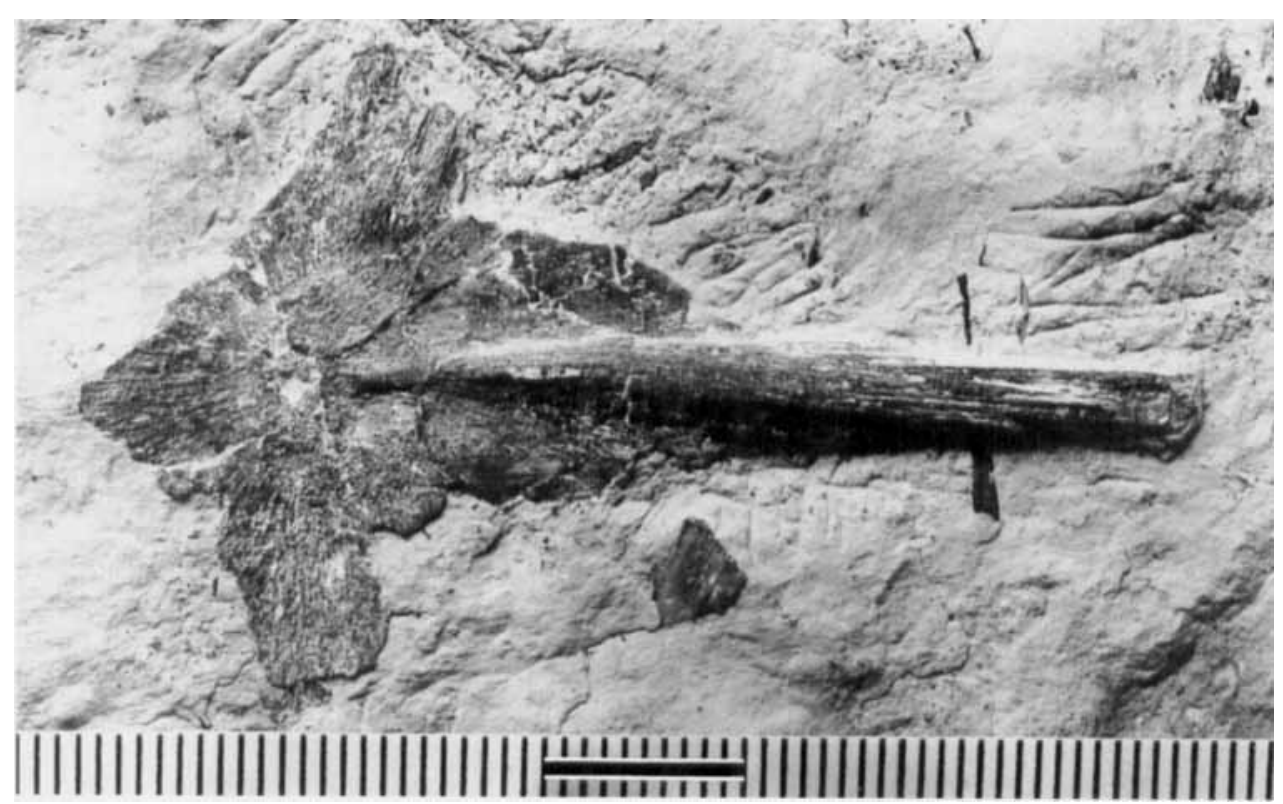

Fig. 3. Dipnoan parasphenoid, FMNH PF614, in ventral view. Upper Devonian, Deadman's Gulch, Colorado. Scale represents $1 \mathrm{~cm}$

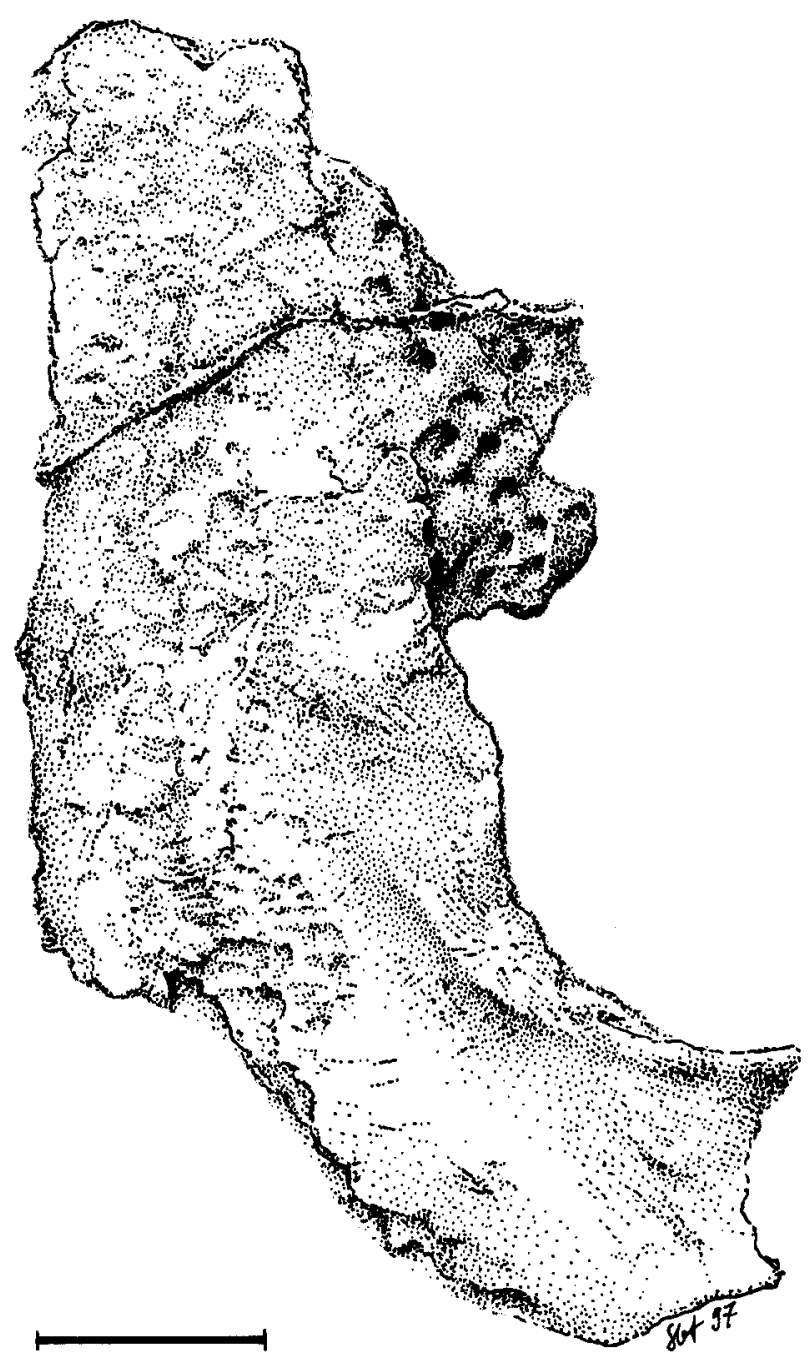

Fig. 4. Dipnoan right pterygoid, KUVP 124466, in dorsal view. Upper Devonian, Brew locality, Colorado. Scale represents $1 \mathrm{~cm}$ than bone $\mathrm{J}$ and bone $\mathrm{B}$ is nearly constant in width throughout its length (Lehman 1959; Campbell \& Bell 1982), but not widening anteriad as in FMNH PF582. In contrast, the size relation between $Y_{2}$ (larger) and $Y_{1}$ is not found in other long-snouted dipnoans. The skull roof belongs to a long-snouted dipnoan, a rhynchodipterid close to Soederberghia, but is distinct in the shape of bone $\mathrm{B}$ and the large size of bone $\mathrm{Y}_{2}$.

Parasphenoid: The parasphenoid FMNH PF614 (Fig. 3) is typical of advanced dipnoans. It has a body with lateral wings that form an acute angle with the posterior part of the body. The body diminishes in width gradually towards the stem. The stem is long and narrow. It appears that a buccohypophysial foramen is present. The parasphenoid compares in shape most closely with Carboniferous dipnoans. A parasphenoid with a lozenge without lateral wings and with a long stem is also known from the Late Devonian Oervigia (Lehman 1959: fig. 27).

Pterygoid: Specimen KUVP 124466 (Fig. 4) shows the impression of the dorsal side of a right pterygoid. The median margin is straight; the margin for contact with the parasphenoid runs obliquely from the median margin towards the quadrate portion of the pterygoid. The shape of this contact conforms well with the anterior margin of parasphenoid FMNH PF614. At the lateral margin the impression of the tooth plate is visible. A cast of the unprepared specimen shows impressions of denticle rows. There are 6-7 rows of round denticles arranged on ridges. 
The tooth plate compares with Dipterus mordax, $D$. pectinatus and $D$. johnsoni, the first two species described by Eastman (1915) from the Elbert Formation, the third by Bryant (in Bryant \& Johnson 1936) from the lower part of the Chaffee Formation. All three species may be conspecific (Denison 1951), characterized by tooth plates with $6-8$ ridges with round, well separated denticles such as in the tooth plate KUVP 124466 from the Brew locality and FMNH PF583 from Endlich Mesa.

Cleithrum: The left cleithrum of a dipnoan, FMNH PF14903 (Fig. 5), is preserved on block FMNH PF619 from Deadman's Gulch. It shows

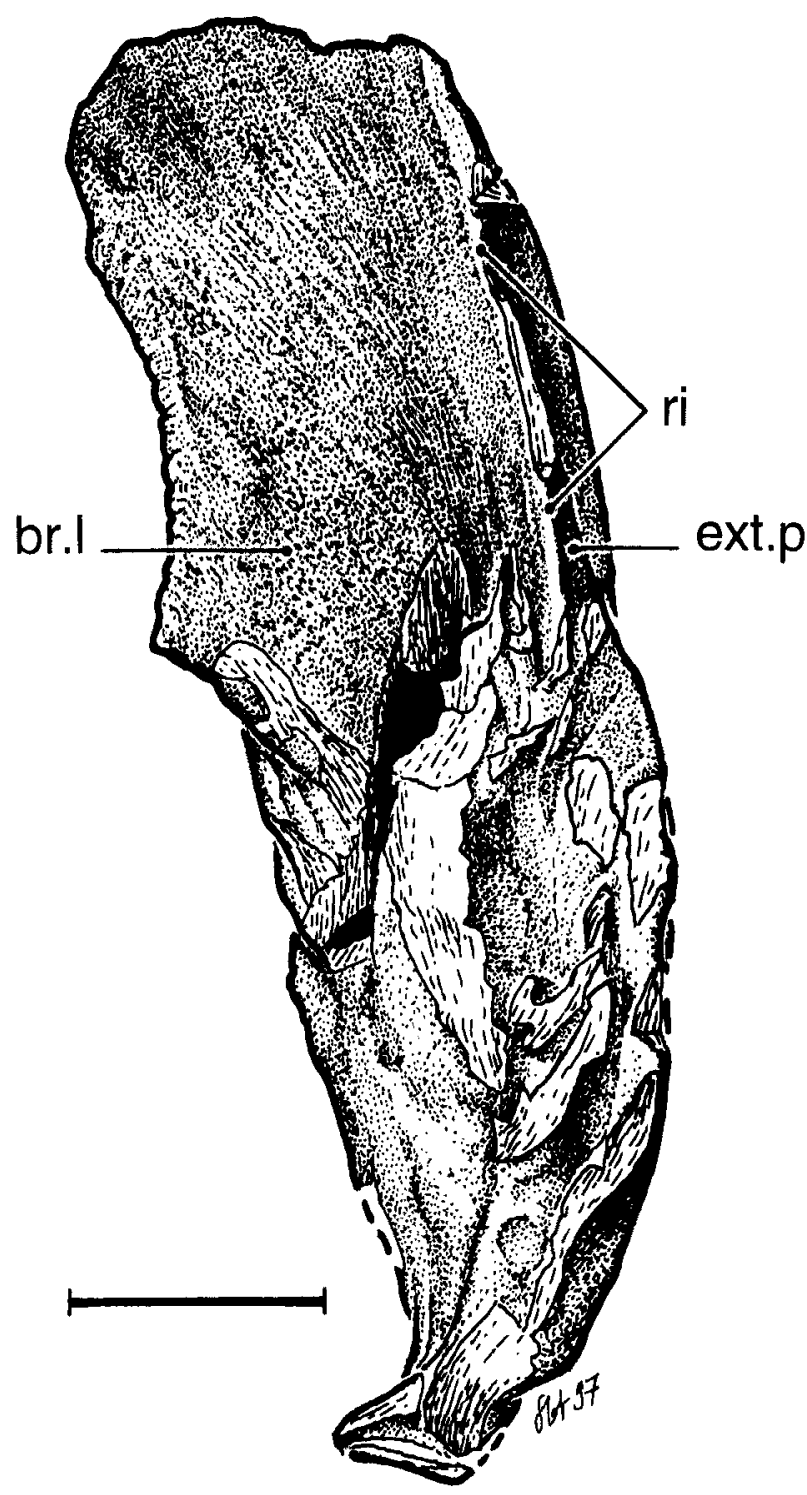

Fig, 5. Dipnoan left cleithrum, FMNH PF14903, in anterolateral view. Upper Devonian, Deadman's Gulch, Colorado. br.l, branchial lamina; ext.p, external portion; ri, ridge between branchial lamina and external portion of the cleithrum. Scale represents $1 \mathrm{~cm}$ a broad branchial lamina separated by a ridge from a narrow external portion. The ridge is broken and thus visible in the upper half, but difficult to follow in the lower half. It ends at the corner between the posterior and dorsal margin. The posterior margin forms a shallow arch. The dorsal margin indicates an arch despite its broken border; it continues into an anteromedial concave border. The concave border ends with a sharp corner followed by a irregularly limited lower part of the branchial lamina. The contact with the clavicle appears very narrow. The cleithrum is narrow, as are the cleithra of other Devonian lungfish (Jarvik 1980: fig. 335; Campbell \& Barwick 1987: fig. 11), but it lacks the typical broad contact with the clavicle. In its broad branchial lamina compared to the small external portion and its division into a dorsal invagination and lower straight portion of the anteromedial border, the cleithrum approaches Carboniferous dipnoans such as Sagenodus (Schultze \& Chorn 1997: fig. 34).

Ribs: On specimen KUVP 124478, the proximal part of five thick ribs are associated with a scale cover. The two ribs in the material of Deadman's Gulch also occur together with round scales, but the association is not as close as in specimen KUVP 124478. On specimen FMNH PF616, a fin supporting element is preserved. It has a narrow proximal part and a broad triangular distal end.

Scales: The Brew locality yields both round scales with small tubercles and ridges on their surface and round scales with a smooth surface. The former are more elongated and assigned to holoptychiids, whereas the later are probably those of dipnoans, in part, based on the association with ribs on specimen KUVP 124478. These scales have only a narrow unornamented exposed (free) field. They are more square (as deep as or deeper than long) than those of holoptychiids. They do not possess cosmine, and could belong to a rhynchodipterid.

\section{Comparison}

All the dipnoan bones of the Upper Devonian of Colorado show features transitional from Late Devonian to Carboniferous forms. The parasphenoid and cleithrum appear very advanced. The skull roof pattern indicates a long-snouted dipnoan, whereas the remains of the pterygoid tooth plate indicate a short-snouted form. Dipnoan re- 
mains probably represent at least two different dipnoans, one or more of which bore many advanced ('Carboniferous') features.

\section{Onychodontida}

Onychodont teeth have been recognized by Johnson \& Elliott (1995) in the Martin Formation of Northern Arizona. Two are present in the material from Deadman's Gulch collected by Denison in 1949 and 1950, and possibly one occurs at the Brew locality.

\section{Onychodont}

Material

Deadman's Gulch: Teeth on back of FMNH PF598, PF611 and PF614.

Brew locality: Tooth: KUVP 124541.

\section{Porolepiformes}

\section{Holoptychiidae}

Some of the thin round scales from Deadman's Gulch assigned to Litoptychus by Denison (1951) belong to holoptychiid sarcopterygians. Small tubercles in radiating rows precede the ridges of the free field (Denison 1951: fig. 42B). The group can be undisputably identified by its teeth. No holoptychiid bone was identified.

\section{Holoptychiid}

\section{Material}

Deadman's Gulch: Round scales: FMNH PF 598 (inner side, and one tooth), PF613 (section 4236), PF615, PF617 (pieces of round scale; Denison 1951: fig. 42B).

Boulder Lake: Teeth: FMNH PF585 (sections 4248 to 4250), PF586 (sections 4243-4247).

Brew locality: Tooth with sharp anterior and posterior edges: KUVP 124482, 124524. Round scale: KUVP 124505.

\section{Holoptychius ef. giganteus}

\section{Material}

Boulder Lake: Scales and plates: FMNH PF584. Endlich Mesa: Lower jaw: FMNH PF579 (impression). Round scales: FMNH PF575 (impression), PF576 (impression), PF577 (impression), PF578 (impression). Indet. plate: FMNH PF580.

\section{Osteolepiformes}

\section{Osteolepididae}

Osteolepidids are the most common fossils at the Brew locality. A smaller osteolepidid with cosmine (co), and a larger one without cosmine and with coarse ornamentation (tu) are present at the Brew locality, Deadman's Gulch and Spar Gulch. There are bones and scales with both tubercles and cosmine (compare Denison 1951: fig. $47 \mathrm{~A}, \mathrm{C})$. These and the bones and scales with coarse tuberculation are assigned to Litoptychus. The smaller osteolepidid with cosmine covered scales and bones represents a form close to Gyroptychius.

\section{Osteolepididae indet.}

\section{Material}

Deadman's Gulch: Rhombic scales: FMNH PF599 (co = Denison 1951: fig. 47B), PF600 (two scales, inner view), PF611 (co), PF614 (co), PF616 (co), PF618 (inner view), PF5565 (co), PF14916 (co, elongated scale or bone).

Spar Gulch: Bony plate: FMNH PF607. Rhombic scales: FMNH PF597 (co), PF605 (impression), PF606 (co), PF616 (co; section 4232).

Brew locality: Nearly complete fish: KUVP 124501 (co). Bodies: KUVP 124502 (co), 124508 (co), 124514 (co), 124533 (co), 124550 (co), 124555 (poorly preserved body, co), 124568 (co). Posterior head: 124549 (co), 124569 (co). Gular region: 124533 (co). Lower jaws: KUVP 124460 (co), 124463 (co), 124510 (?). Rhombic scales: KUVP 124478 (co), 124503 (co), 124523 (co).

\section{Description}

Skull roof (Fig. 6): Despite the presence of nearly complete osteolepidid specimens, there is none with a completely preserved skull roof. Specimen KUVP 124569 shows the posterior part of the skull roof with postparietal, tabulars, extratemporals and extrascapulars. The postparietals are fused together into an unpaired bone flanked by tabulars. The tabulars are not wider than the extratemporals. The narrow median extrascapular is about half the width of either lateral extrascapular.

Gular region (Fig. 7): The principal gular plates are elongated $\left(2 \frac{1}{2}\right.$ to 3 times as long as wide). The left gular overlaps the right in ventral view. Part of the median gular plate lies on the left gular. Five submandibulars fill the space between gular and lower jaw, followed by the partly preserved last submandibular (submandibulobranchiostegal). 


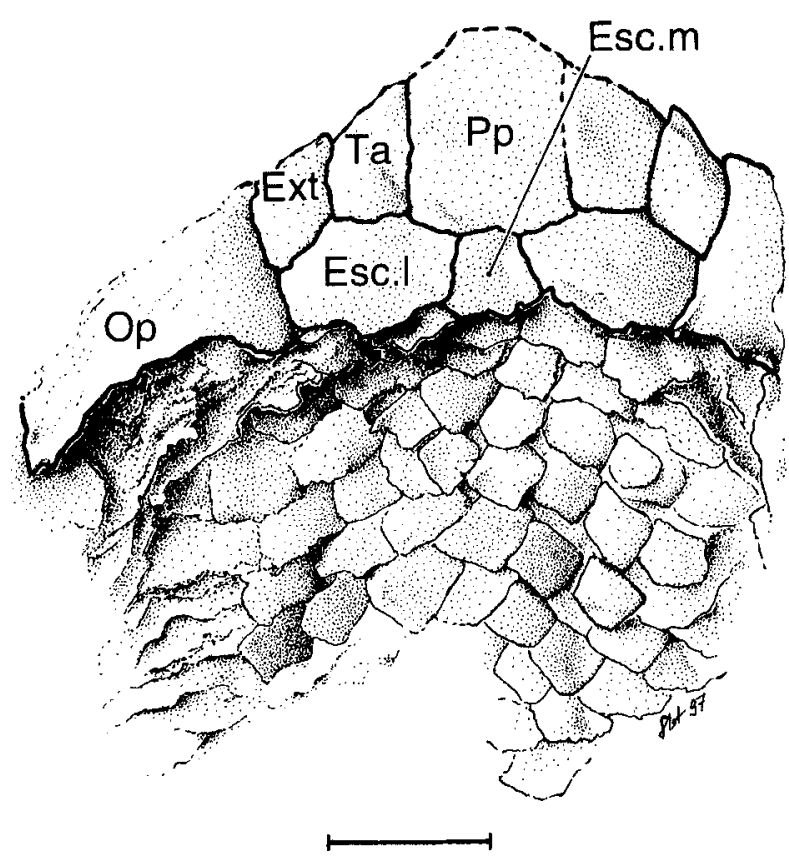

Fig. 6. Osteolepidid skull roof, KUVP 124569, in dorsal view. Upper Devonian, Brew locality, Colorado. Esc.l, Esc.m, lateral, median extrascapular; Ext, extratemporal; Op, operculum; Pp, postparietal; Ta, tabular. Scale represents $1 \mathrm{~cm}$

Body (Fig. 8): The body is covered by rhombic scales. Denison described cosmine covered rhombic scales from Deadman's Gulch (Denison 1951: fig. 47B) and Spar Gulch. These are not assignable to genus or species because they lack distinguishable features, however, they conform with scales found on the nearly complete osteolepidid of the Brew locality.

\section{Comparison}

Only the most posterior part of the skull roof and the gular region are available for comparison with osteolepidids with cosmine covered bones and scales (Tab. 1). Relationships of the extrascapular, extratemporal, tabular, and the lateral gular place the osteolepidid close to $O s$ teolepis and Gyroptychius. The smaller tabular of

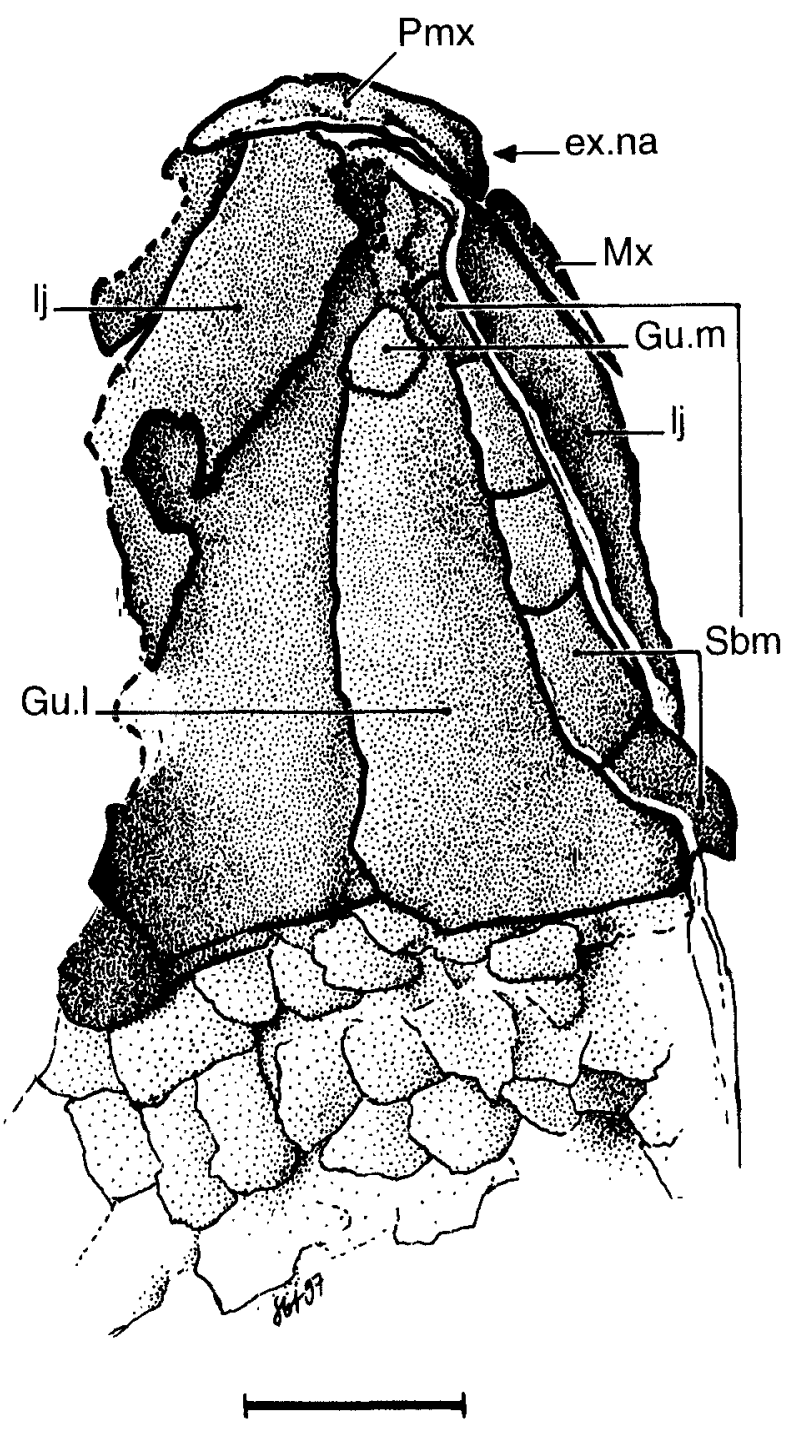

Fig. 7. Gular region of specimen KUVP 124501, in dorsal view. Upper Devonian, Brew locality, Colorado. ex.na, anterior external nasal opening; Gu.l, Gu.m, lateral, median gular; lj, lower jaw; Mx, maxilla; Pmx, premaxilla; Sbm, submandibular. Scale represents $1 \mathrm{~cm}$

Gyroptychius is similar to that of the osteolepidid of Colorado. Medoevia, an osteolepidid from Russia (Lebedev 1995), resembles Gyroptychius in these relationships and thus also the Colorado osteolepidid.

Table 1. Comparison of osteolepidid from Colorado with other cosmine covered osteolepidids

\begin{tabular}{llllll}
\hline & osteolepidid & Osteolepis $^{1}$ & Gyroptychius $^{2}$ & Gogonasus $^{3}$ & Thursius $^{4}$ \\
\hline width Esc.m/Esc.1 & $1: 2$ & $1: 2 \rightarrow 1: 1$ & $1: 2.3 \rightarrow 1: 1$ & $1: 2.5$ & $1: 2 \rightarrow 1.7$ \\
Ext/Ta & $1: 1$ & $1: 2 \rightarrow 1: 1$ & $1: 1.3 \rightarrow 1: 1$ & $1: 1.5$ & $11: 6.5 \rightarrow 3.2$ \\
Gu width/length & $1: 2.5 \rightarrow 3$ & $1: 2.6 \rightarrow 3.2$ & $1: 2.8$ or $1: 3$ & $1: 2.3$ & $1: 2.8 \rightarrow 3.2$ \\
number of Sbm & 5 & 7 & $? 6$ & 5 & 5
\end{tabular}

${ }^{1}$ Jarvik 1948: fig. 37, tab. 1.

2 Jarvik 1948: fig. 71 , tab. 1.

3 Long et al. 1997: figs. 3A, 34.

${ }^{4}$ Jarvik 1948: fig. 58, tab. 1. 


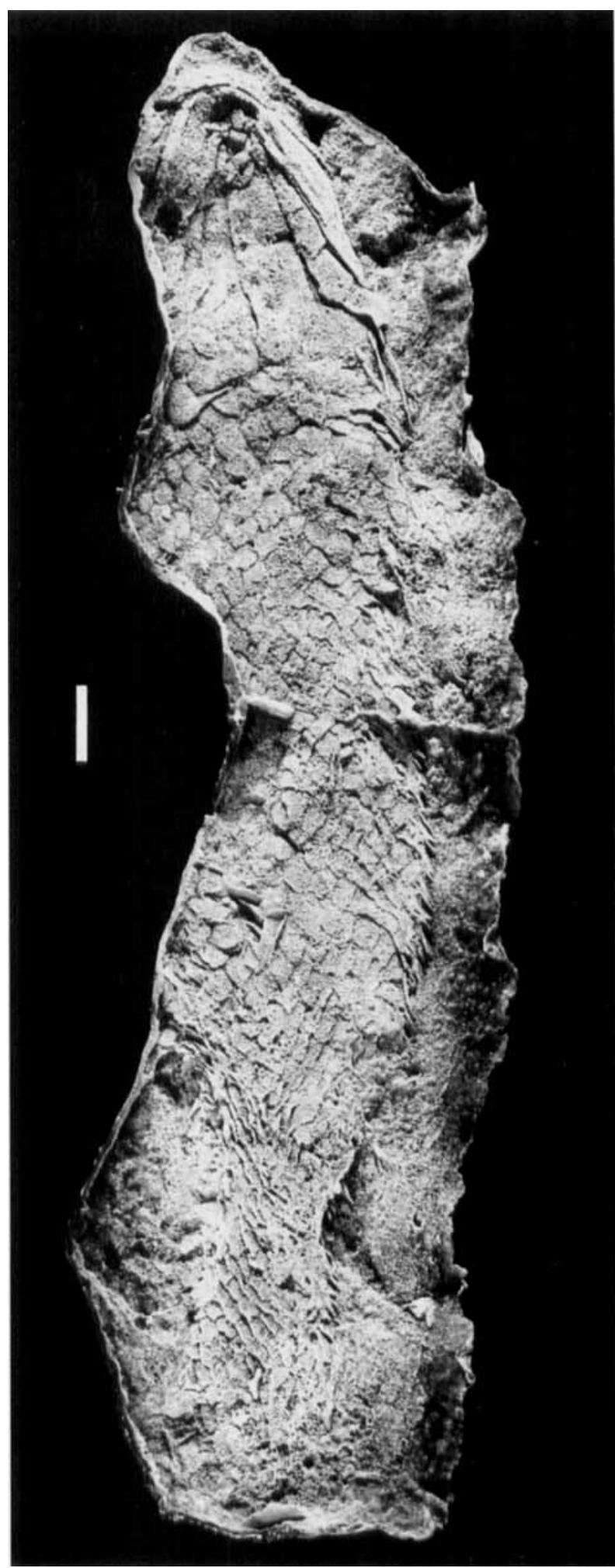

Fig. 8. Osteolepidid body in ventral view. Upper Devonian, Brew locality, Colorado

\section{Litoptychus Denison, 1951}

\section{Synonyms:}

Litoptychus Denison 1951: 241, 247-248 [Rhizodontidae].

Litoptychius [sic] Romer 1966: 361 [Rhizodontidae].

Litoptychus Lehman 1966: 336 [Holoptychiidé].

Litoptychus Schultze 1969: 118 [eusthenodont].

Litoptychius [sic] Carroll 1987: 611 [?Eusthenopteridae].

Denison (1951) based this genus on thin round scales, robust fangs with simple dentine enfolding, dermal bones with tubercles, internal expansion at anterior end of lower jaw and ringshaped vertebrae. These characters are too general to define the genus. The thin round scales do not belong to Litoptychus. Instead they derive from holoptychiids (Ørvig 1957) and dipnoan sarcopterygians. Litoptychus has strongly tuberculated rhombic scales. In addition, Denison misinterpreted the tooth structure because of abundant fungal hyphae (Mycelites) in the teeth. Examination of thin sections under polarized light reveals that Litoptychus has eusthenodont teeth (Schultze 1969: 118).

Diagnosis: An osteolepidid with a fang on the anterior dentary, eusthenodont teeth, long postorbital portion of the palatoquadrate, squamosal forming most of the cheek, small postorbital and jugal, and large quadratojugal separating the narrow vertical preoperculum for most of its length from the squamosal. The palatoquadrate has a deep posterior portion so that the quadrate-articular articulation lies above the ventral margin of the palatoquadrate. Rhombic scales and ring centra are present.

Type species: Litoptychus bryanti Denison, 1951 Time: Late Devonian

\section{Litoptychus bryanti Denison, 1951}

\section{Synonyms:}

Litoptychus bryanti Denison 1951: 241-247, figs 43-47A, C (not fig. 42) [Rhizodontidae].

Litoptychus bryanti Ørvig 1957: 394-395, figs 7A, B, tab. between p. 406 and 407 [holoptychiid].

Litoptychus bryanti Vorobyeva \& Obruchev 1964: 290 [Holoptychiidae].

Litoptychus bryanti Jessen 1967: 331-333, fig. 5A [Osteolepider].

Litoptychus bryanti Schultze 1969: fig. 22, pl. 1: 5.

Denison (1951) described Litoptychus only from Deadman's Gulch with a lower jaw as the holotype showing the lingual side. In addition to a second lower jaw from Deadman's Gulch, lower jaws from Little Cascade Creek, Endlich Mesa and the Brew locality are assigned to Litoptychus. Litoptychus is represented by skull material 
at Deadman's Gulch and the Brew locality. A ring centrum is associated with the skull, KUVP 124448 , from the Brew locality and with a posterior head shield, FMNH PF 14909, from Deadman's Gulch. Denison (1951) was correct to assign ring centra to Litoptychus, whereas he missed the association of Litoptychus with strongly tuberculated rhombic scales. These scales occur at Deadman's Gulch, Spar Gulch and the Brew locality.

Holotype: FMNH PF610 (holotype = Denison 1951: fig. 46) Locus typicus: Deadman's Gulch. Central Colorado Horizon: Parting Formation, Chaffee Group, Frasnian, Late Devonian.

Diagnosis: Bony tubercles on skull bones and rhombic scales, sometimes partial cosmine cover; no visible sutures on anterior head shield; gulars $2 \frac{1}{2}$ times longer than wide; palatoquadrate with low anterior (depth $=34 \%$ of length) and deep posterior (depth $=57 \%$ of length) part of postorbital portion; elongated postparietals (width $=$ $30 \%$ of length).

\section{Additional material}

Deadman's Gulch: Anterior head shield: FMNH PF14912. Posterior head shield: FMNH PF14908, PF14909, PF14911, PF14913. Palatoquadrate: FMNH PF14907. Pterygoid: ?FMNH PF14904. Cheek: FMNH PF14914.

Lower jaw: PF613 (= Denison 1951: fig. 45). Tooth: FMNH PF616 (section 4235, Denison 1951: fig. 43B, Schultze 1969: fig. 22, pl. 1, fig. 5), PF619 (sections 4240-4242, Denison 1951: fig. $43 \mathrm{~A}=$ section 4242). Dermal bone: FMNH PF619 (sections 4237-4239), ?PF14906. Centra: FMNH PF611 (three), PF614, PF14910, PF14917. Rhombic scales: FMNH PF598 (scale with both tu $+\mathrm{co}=$ Denison 1951: fig, 47C, and one tooth), PF601 (2 scales: tu + co, and bone pieces, section 4234), obverse of PF614 (tu $+\mathrm{co})$, ?PF14905.

Spar Gulch: Rhombic scales: FMNH PF603 (tu $=$ Denison 1951: fig. 47A, and inner view of large scale), PF604 (co $+\mathrm{tu}$ ). Bone: FMNH PF607 (tu and reticulate ornamentation) Endlich Mesa: Lower jaw: FMNH PF581.

Little Cascade Creek: Lower jaw: ?FMNH PF602 (tu). Brew locality: Head: KUVP 124448 (tu). Posterior head: KUVP 124449 (tu), 124525 (tu), ?124527 (?tu). Median extrascapular: KUVP 124534 (tu). Gulars: KUVP124452 (co + tu), ?124474 (tu). Lower jaw: KUVP 124500, 124558. Cleithrum: KUVP 124452 (tu). Centra: KUVP 124458, 124465, $124469,124476,124487,124488,124493,124547$ (negative), 124559,124563 (negative), 124564, 124565 (negative), 124566 (negative). Rhombic scales: KUVP 124467 (tu), 124468 (tu), 124470 (tu), 124473 (co + tu), 124484 (tu), 124486 (tu), 124490 (tu), 124495 (tu), 124498 (tu), 124503 (tu), 124504 (tu), 124506 (co + tu), 124507 (tu), 124509 (tu), 124516 $(\mathrm{co}+\mathrm{tu}), 124517$ (tu), 124518 (tu), 124519 (tu), 124520 (tu), 124521 (?tu), 124537 (?tu), 124545 (co + tu), 124546 (co + $\mathrm{tu}), 124551(\mathrm{tu}), ? 124553(\mathrm{tu}), 124554(\mathrm{tu}), 124562(\mathrm{tu})$, $127058(\mathrm{tu})$. Isolated bones: KUVP $124485(\mathrm{co}+\mathrm{tu}), 124512$, $124513,124527,124532$.

\section{Description}

The holotype of $L$. bryanti is an incomplete left lower jaw, FMNH PF610. Denison (1951) referred large round scales $(30 \times 25 \mathrm{~mm})$, robust fangs, three lower jaws, an operculum, a parasphenoid and ring-shaped centra to the species. He mentioned fragments of the endocranium and skull bones (p. 246--247, 256), but did not describe them because they "are not sufficiently complete".

The assignment of the round scales to Litoptychus is uncertain. Ørvig (1957: 394-395) placed the scales within Holoptychiidae based on radiating rows of small tubercles on the posterior part of the overlapped portion and lack of a central boss-like prominence or ridge on the inner side of the scales. Some of the round scales lack the small tubercles and ridges on the scale surface typical of holoptychiid scales; they are referred here to dipnoans. The parasphenoid is clearly that of a dipnoan. Thus genus and species are defined by the lower jaw and eusthenodont teeth. The ornamentation of the skull bones mentioned by Denison conforms with that of the lower jaws and consequently this material can be attributed to $L$. bryanti. It is described here.

Lowerjaw (Denison 1951: fig. 46): The holotype, FMNH PF610 shows two coronoids and the adsymphysial tooth plate $\left(\mathrm{dn}_{2}\right.$ of Denison 1951) in front of coronoid 1. A small fang (df of Denison 1951) sits on the anterior end of the dentary lateral to the adsymphysial tooth plate. This is a unique feature within Osteolepididae (also in FMNH PF613). Splenial (part of Denison 1951) and postsplenial are seen below the adsymphysial tooth plate and coronoids, followed by the angular. The prearticular and posterior end of the jaw are not preserved.

The external side (Denison 1951: fig. 45) is covered by small tubercles so that the sutures are not discernable except on the posterior part of the dentary. The lower jaw has about the same depth throughout its length. The tooth structure is eusthenodont (simple folding of orthodentine with a pulp cavity filled by osteodentine in the upper part. Schultze 1969: fig. 22).

Skull roof: Denison left unprepared five pieces from Deadman's Gulch with one number (FMNH PF619). Two pieces were prepared and contain many bones of Litoptychus. In addition, block FMNH PF615 with some bones of Litoptychus was also prepared. 


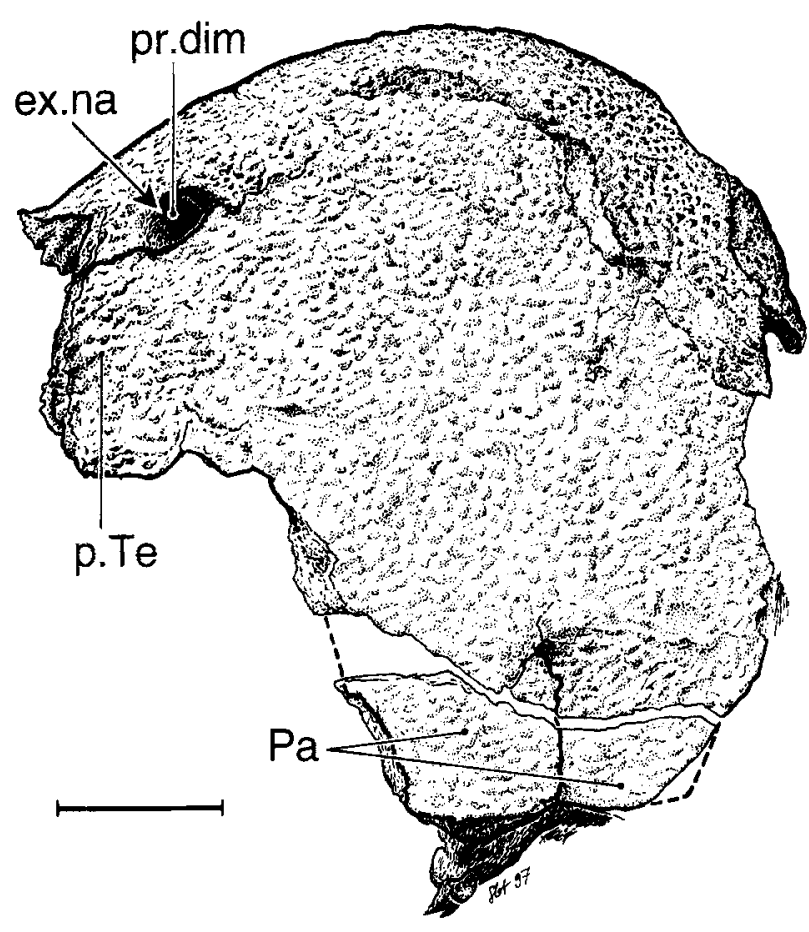

Fig. 9. Litoptychus bryanti, Upper Devonian, Deadman's Gulch, Colorado. Anterior head shield, FMNH PF14912, in dorsal view. ex.na, anterior external nasal opening; Pa, parietal; pr.dim, processus dermintermedius; p.Te, posterior tectal. Scale represents $1 \mathrm{~cm}$

On FMNH PF619, there are one anterior head shield, four posterior head shields, a "cheek" and a palatoquadrate. The anterior head shield, FMNH PF14912 (Fig. 9), is compressed obliquely on the right side so that only the left side is preserved more or less correctly. Sutures are obscured by the tuberculate ornamentation. The posterior part of the median suture between the parietals is visible, as is the anterior boundary of the posterior tectal. The external nasal opening shows the declining surface of the processus dermintermedius. The premaxilla cannot be separated from the lateral rostral which lies in front of the posterior tectal. Lateral rostral and premaxilla form a triangular area overlapped by the maxilla at the anterolateral corner of the anterior head shield. The lateral margin of the posterior tectal forms the overlap area for the lacrimal. The parietal has areas overlapped by supraorbital and intertemporal. At the posterior end of the anterior head shield the simple attachment to the posterior head shield is exposed above the endocranium.

The posterior head shield (Fig. 10) has elongated (width $=30 \%$ of length) postparietals. The postparietals are twice as broad posteriorly as in the anterior part. The posterior suture of the supratemporal extends mediad. This extension is

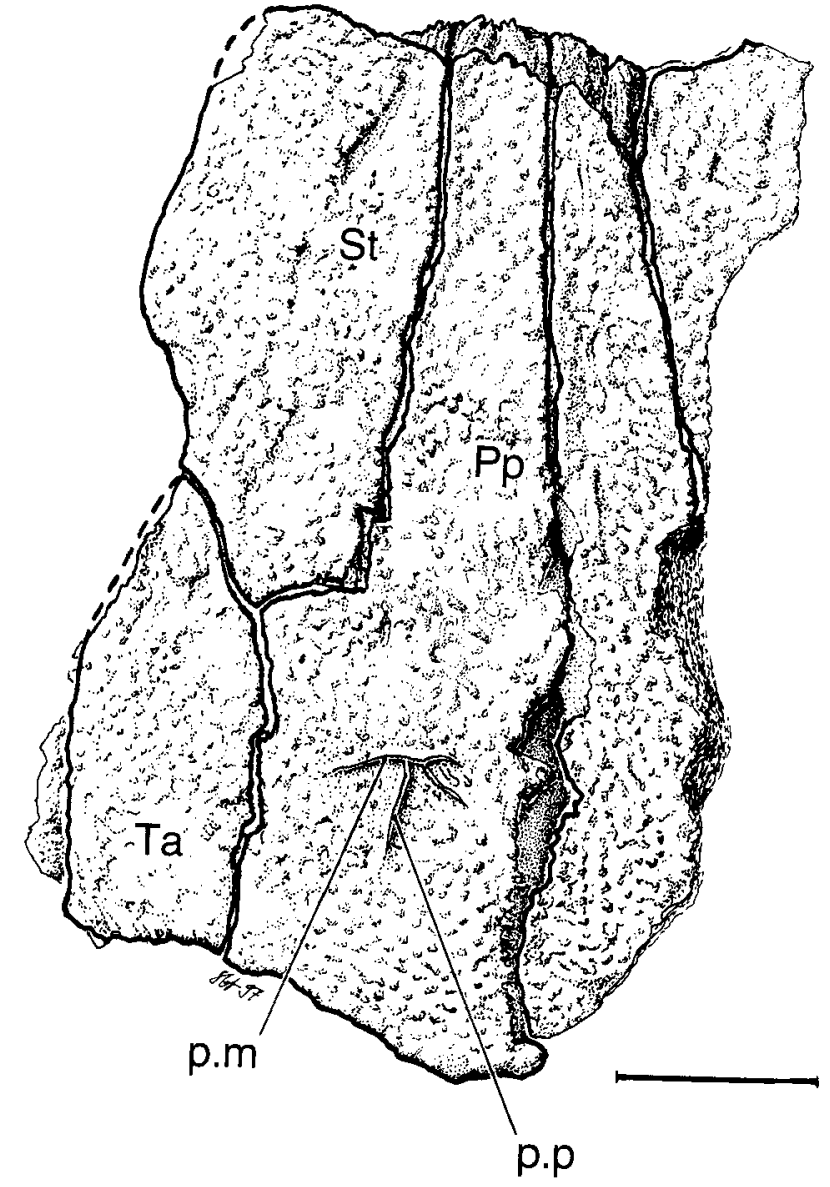

Fig. 10. Litoptychus bryanti, Upper Devonian, Deadman's Gulch, Colorado. Posterior head shield, FMNH PF14911, in dorsal view. p.m, middle pit line; p.p, posterior pit line; Pp, postparietal; St, supratemporal; Ta, tabular. Scale represents $1 \mathrm{~cm}$

not as pronounced in FMNH PF14909 and 14913. The postparietals narrow anteriad where they end with an area overlapped by the anterior head shield. Middle and posterior pit lines are developed on postparietals. The tabular has a pointed anterolateral end in FMNH PF14909 and 14911, but a straight suture with the supratemporal in FMNH PF14913. The anterior lateral side of the tabular forms the medial margin of the spiracular slit. The supratemporal is longer than wide (width $=45 \%$ in PF14911 and $=$ $73 \%$ of length in PF14913).

The posterior part of the endocranium, the otico-occipital region is preserved in two specimens, FMNH PF14908 and PF14909. In posterodorsal view (Fig. 11A), a broad canal for the notochord is followed dorsad by a smaller canal for the neural cord and a small depression for the attachment of the supraneural ligament. The otico-occipital region is shown in ventral view in Fig. 11B, so that the space for the notochord appears to be on top followed below by a broader 

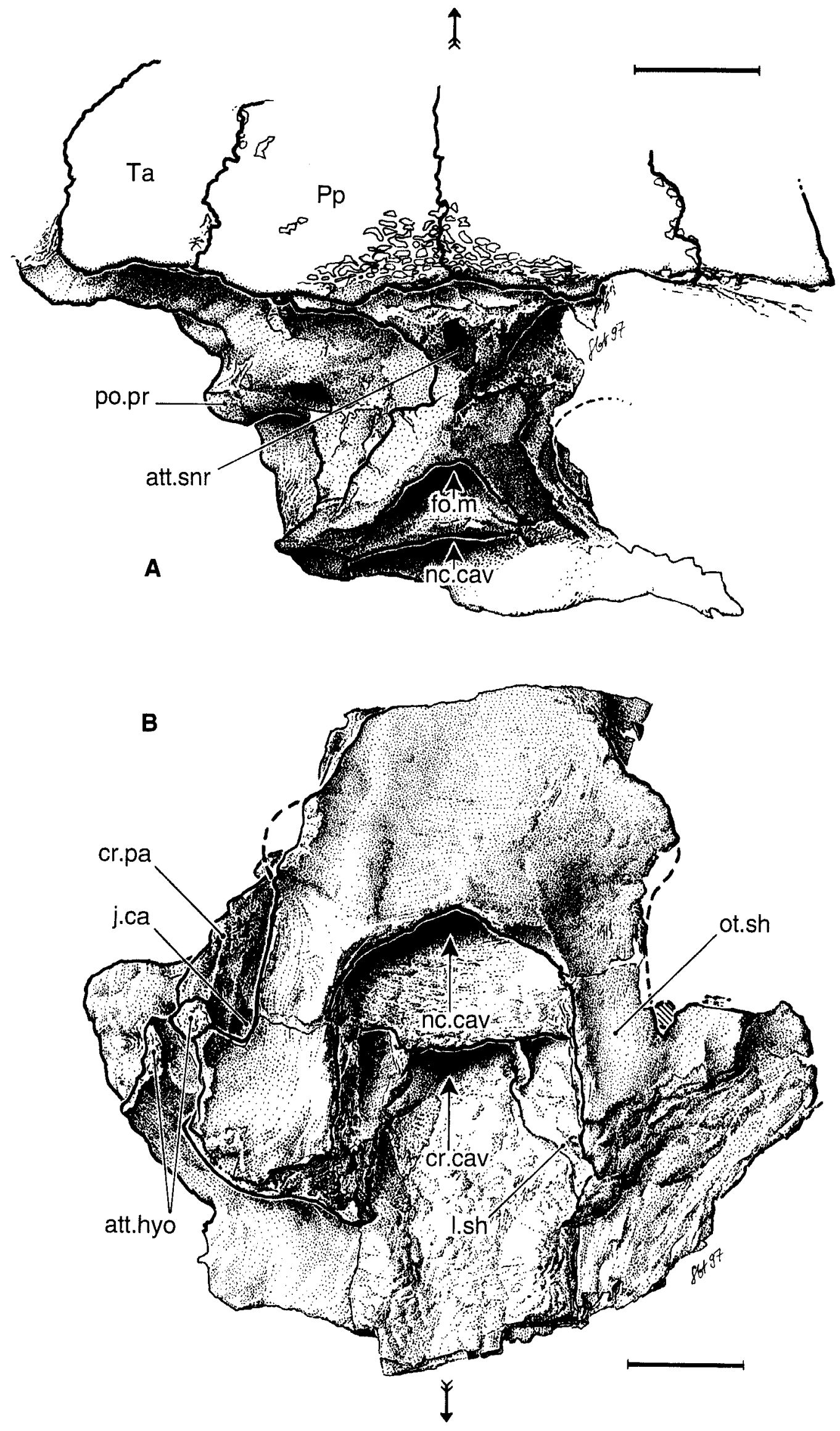

Fig. 11. Litoptychus bryanti, Upper Devonian, Deadman's

Gulch, Colorado, Otico-occipital endocranium, FMNH

PF14908. A. Posterodorsal view. B. Anteroventral view. att.hyo, attachment areas of hyomandibula; att.snr, attachment of supraneural ligament; cr.cav, cranial cavity; cr.pa. crista parotica; fo.m, foramen magnum; j.ca, jugal canal; l.sh, lateral shelf; nc.eav, notochordal cavity; ot.sh, otical shelf; po.pr, postotic process. Arrows point anteriad. Scale represents $1 \mathrm{~cm}$ 


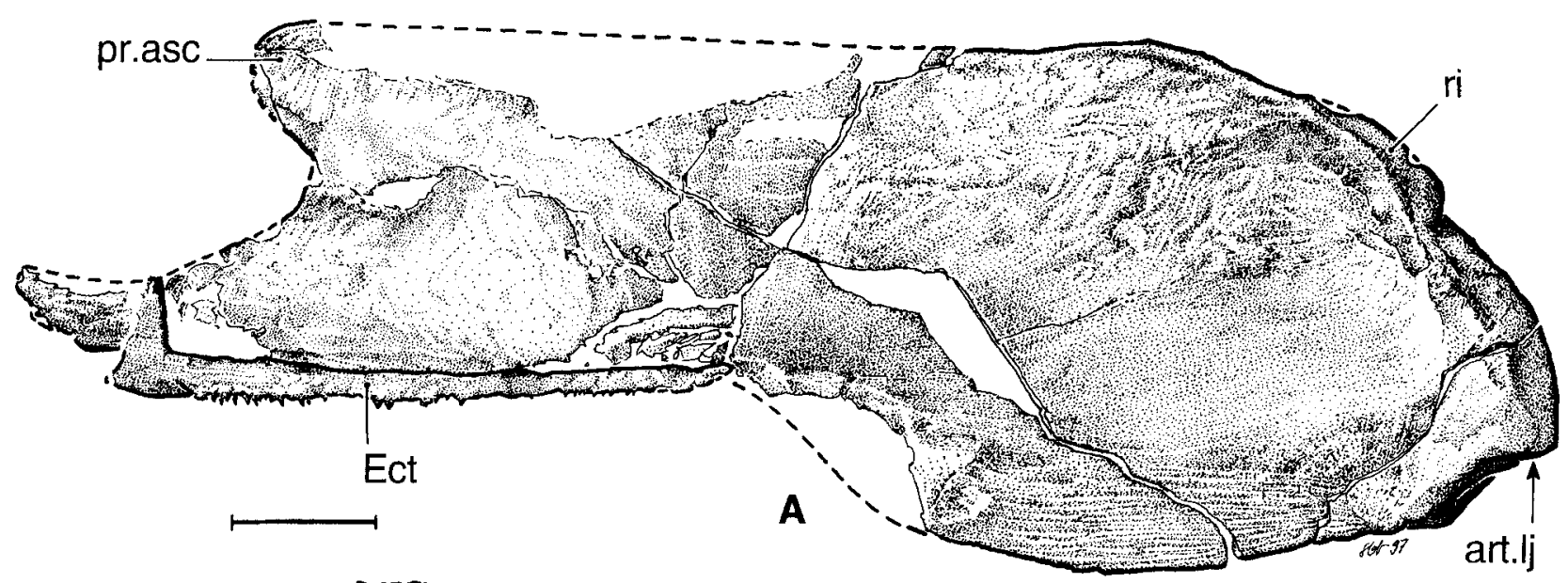

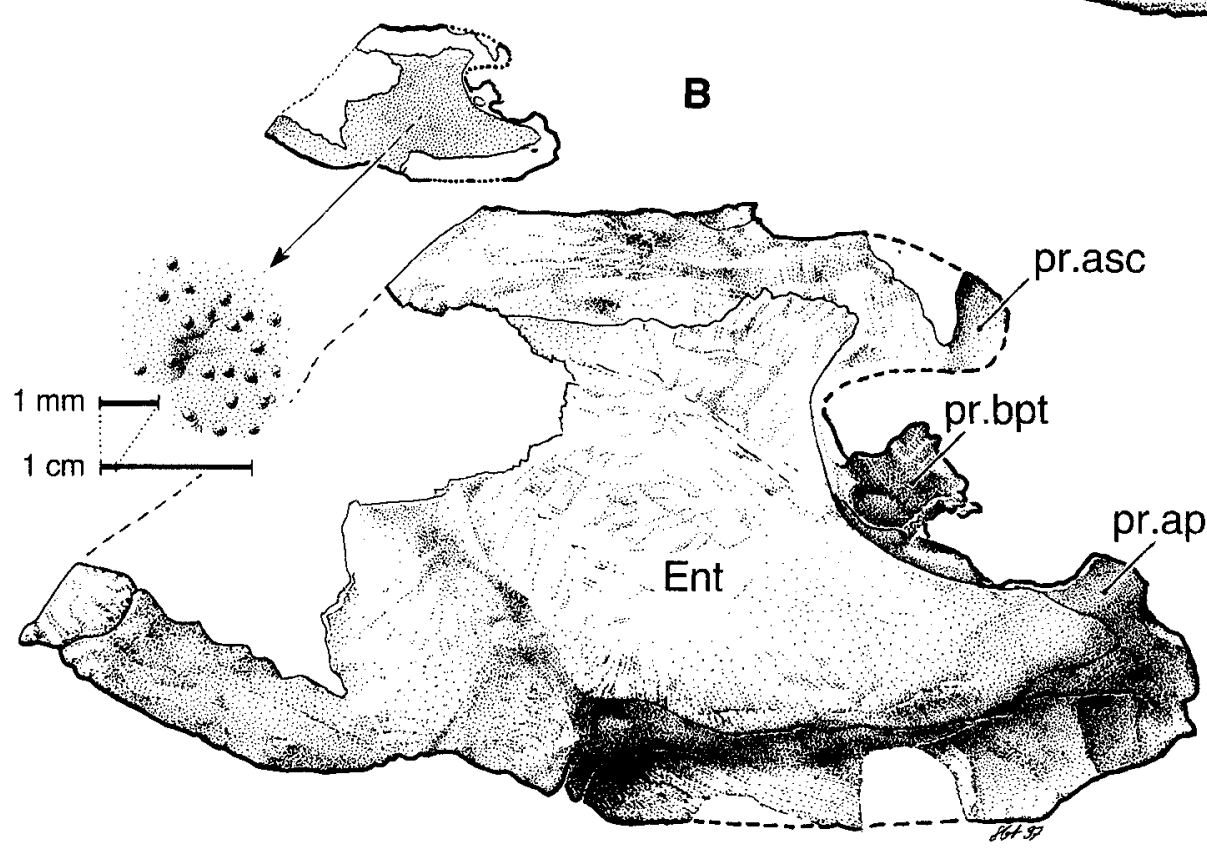

Fig. 12. Litoptychus bryanti. Upper Devonian, Deadman's Gulch, Colorado. Palatoquadrate. A. FMNH PF14907 in lateral view. B. FMNH PF14904, anterior part in medial view with toothed entopterygoid. art.lj, articulation with lower jaw; Ect, ectopterygoid; Ent, entopterygoid; pr. ap, processus apicalis; pr.asc, processus ascendens; $\mathbf{i}$, ridge. Scale represents $1 \mathrm{~cm}$ and wider cranial cavity, and separated from it by a shelf. On the lateral side, the jugular canal is situated medial to the crista parotica. The otic shelf reaches laterally and forward on both sides of the basicranial fenestra, which opens to the notochordal and cranial cavities. The lateral shelf lies lateral to the cranial cavity above a shelf that separates the notochordal and cranial cavities. The lateral shelves extend rostrad to the cranial roof.

Palatoquadrate: Two palatoquadrates are preserved. Palatoquadrate FMNH PF14907 (Fig. 12A) shows the lateral side, whereas palatoquadrate FMNH PF14904 (Fig. 12B) is seen from the medial side. The former has a long postorbital portion with a low anterior $($ depth $=$ $34 \%$ of length) and a deep posterior (depth $=$ $57 \%$ of length) part. The dorsal margin of the anterior part is not preserved behind the processus ascendens, whereas the posterior portion shows the posterodorsal ridge with an invagination behind a ridge-like elevation. Unlike $E u$ sthenopteron (Jarvik 1954) or Gogonasus (Long et al. 1997) the articulation for the lower jaw does not extend below the ventral margin of the palatoquadrate. Instead it runs posterodorsad. The anterior portion of the palatoquadrate is short ( $31 \%$ length of palatoquadrate), and the borders are not well defined. The ventral part of the lateral side of the ectopterygoid is preserved ventral to the anterior part of the postorbital portion of the palatoquadrate. Only small marginal teeth are seen, none of the fangs. Only the anterior part of palatoquadrate FMNH PF14904 (Fig. 12B) is preserved. It shows the processus autopalatinus and partly the processus ascendens. The processus basipterygoideus is compressed out of its natural position into the plane of the palatoquadrate between the processi autopalatinus and ascendens. It now lies in the orbital bay of the palatoquadrate and is thus direc- 


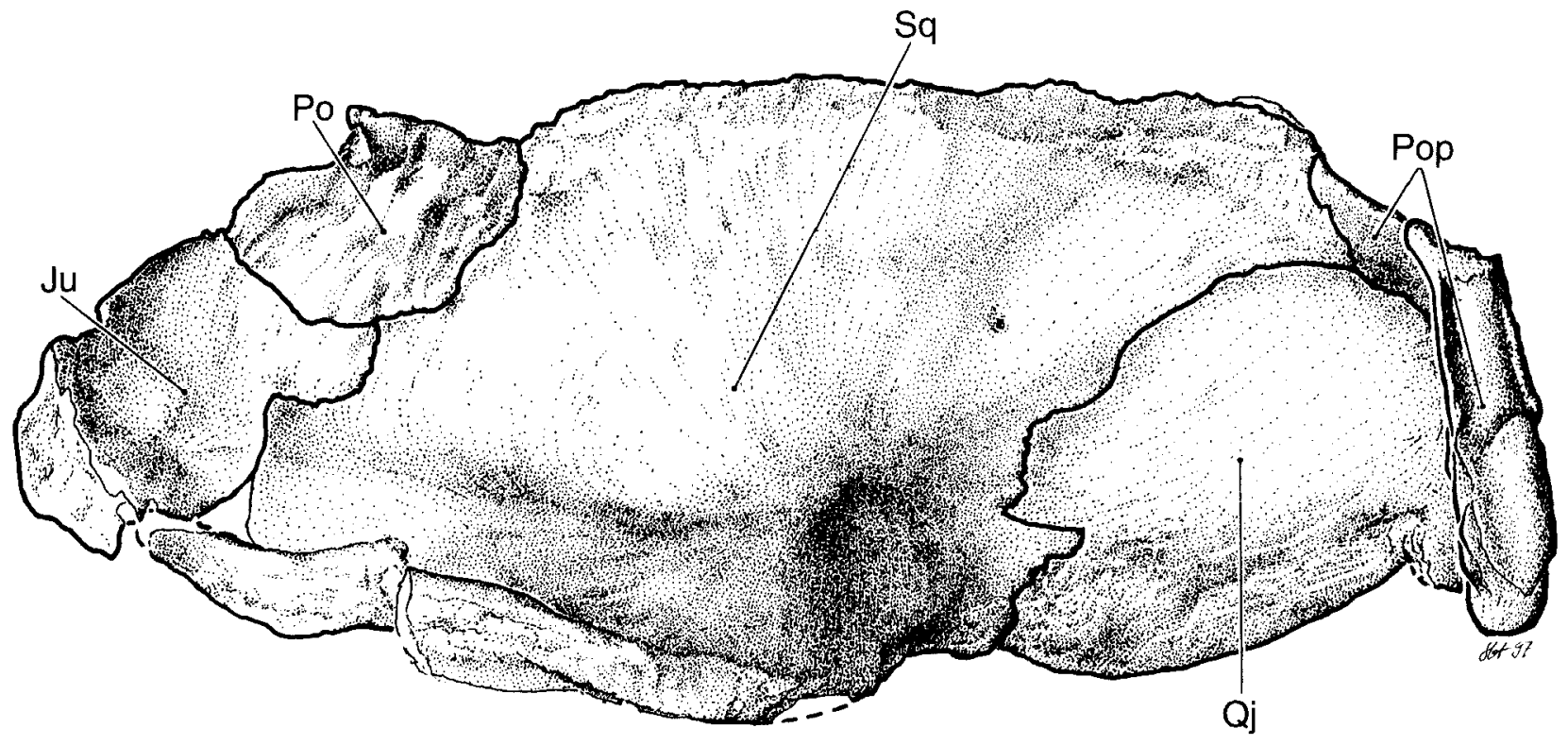

Fig. 13. Litoptychus bryanti. Upper Devonian, Deadman's Gulch, Colorado. Cheek region, medial side, FMNH PF14914. Ju, jugal; Po, postorbital; Pop, preoperculum; Qj, quadratojugal; Sq, squamosal. Scale represents $1 \mathrm{~cm}$

ted anteriad. The entopterygoid is covered with small tubercle-like teeth. An enlargement has been drawn at the left side of the palatoquadrate. Above the palatoquadrate, the distribution of the teeth is shown in a sketch. The teeth are densely distributed in the middle of the entopterygoid and at the margin towards the quadrate articulation.

Cheek (Fig. 13): Specimen FMNH PF14914 shows the medial side of the cheek region with a small postorbital and jugal in comparison to the large squamosal and quadratojugal. Jugal and quadratojugal are widely separated by the squamosal. A thick ridge runs along the ventral margin of the jugal and squamosal. The ridge supports the ventrolateral part of the ectopterygoid. A comparable thick ridge forms nearly the complete medial side of the preoperculum. Such a ridge has been described in Gogonasus (Long et al. 1997: fig. 20). It attaches to the posterior ridge of the palatoquadrate. The preoperculum briefly contacts the squamosal; it lies mostly posterior to the quadratojugal. The elongated cheek region corresponds to the elongated palatoquadrate.

Gular region: The head KUVP 124448 (Fig. 14) shows the two principal gulars in place laterally bordered by submandibulars. These gulars are ornamented with tubercles only, whereas the isolated gular KUVP 124452 is partly cov- ered by cosmine. A horizontal pit line may be present on the right gular of KUVP 124448, whereas none is shown on the cosmine covered area of KUVP 124452. The gulars are about $2 \frac{1}{2}$ times longer than wide, comparable to a similar relationship in Glyptopomus sayrei (2.6-2.7; Newberry 1889: pl. 18, fig. 1), but differing from Glyptopomus kinnairdi $(>5 \times)$ or Eusthenodon $(4 \times)$.

Shoulder girdle (Fig. 15): The left cleithrum is preserved on a different surface of KUVP 124452 than the gular. It shows a narrow branchial lamina, but broader than in Eusthenopteron. It has a steep attachment for the clavicle, but unlike Eusthenopteron there is no overlap towards the clavicle. Anteroventrally it is strongly ornamented by vertical narrow ridges alternating with deep grooves. These give way to a network of ridges and, farther posteriorly, to tubercles. Similar ornament can be found in other osteolepiforms (Beelarongia, Long 1987: fig. 4; Cladarosymblema, Fox et al. 1995: figs 60A, 61C; Eusthenopteron, Jarvik 1944: figs 2B, 3D; Glyptopomus, Jarvik 1950: pl. 6: 3; Rhizodus and Strepsodus, Andrews 1972: pl. I: B, C).

Centra: Denison (1951) assigned ring centra to Litoptychus. These are mostly deformed centra of $14-20 \mathrm{~mm}$ diameter inside and $25-31 \mathrm{~mm}$ diameter outside, with a length of only about $6 \mathrm{~mm}$. Some centra have short extensions for 


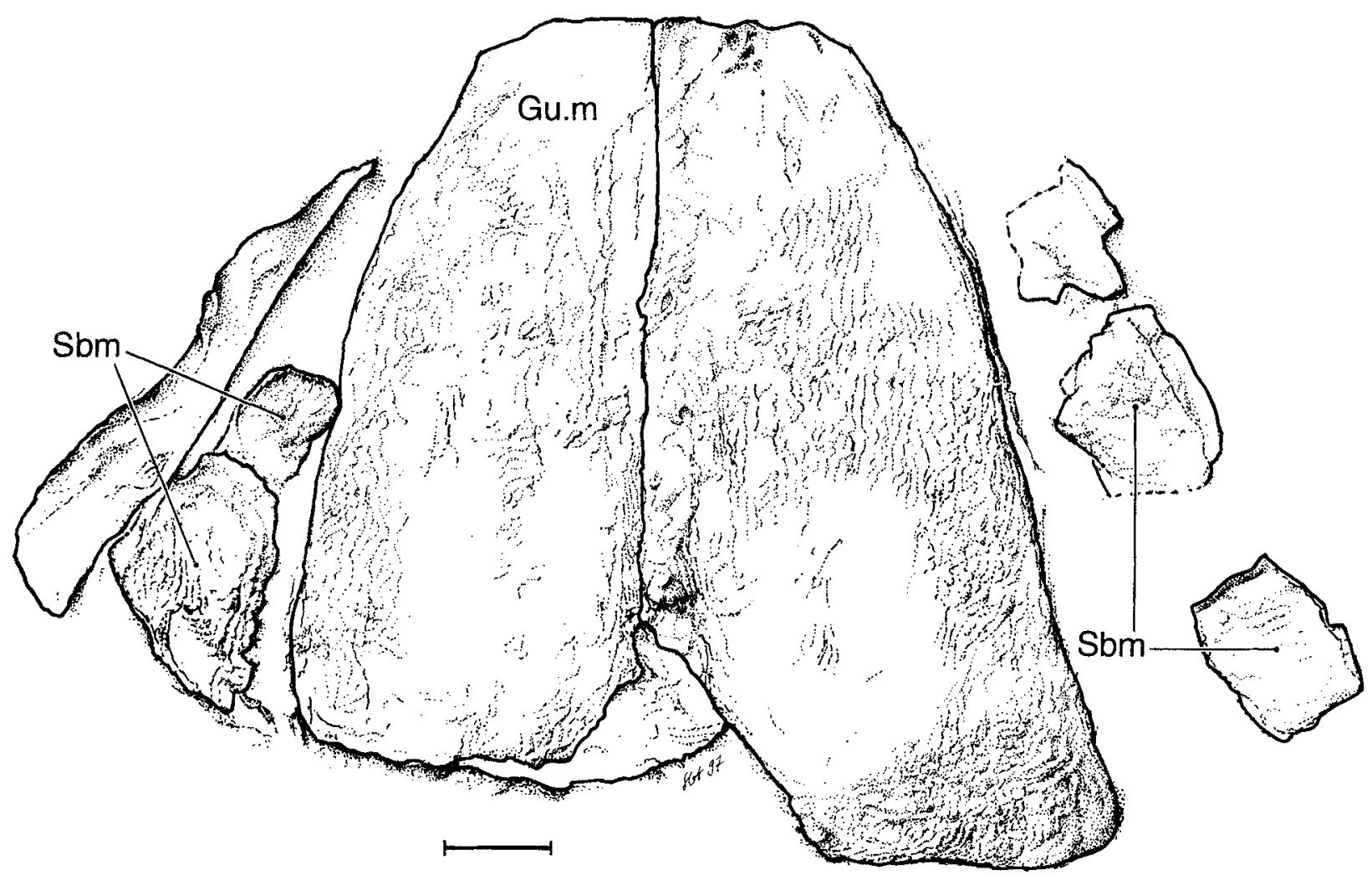

Fig. 14. Litoptychus bryanti. Upper Devonian, Brew locality, Colorado. Gular region KUVP 124448. Gu.m, median gular; Sbm, submandibular. Scale represents $1 \mathrm{~cm}$

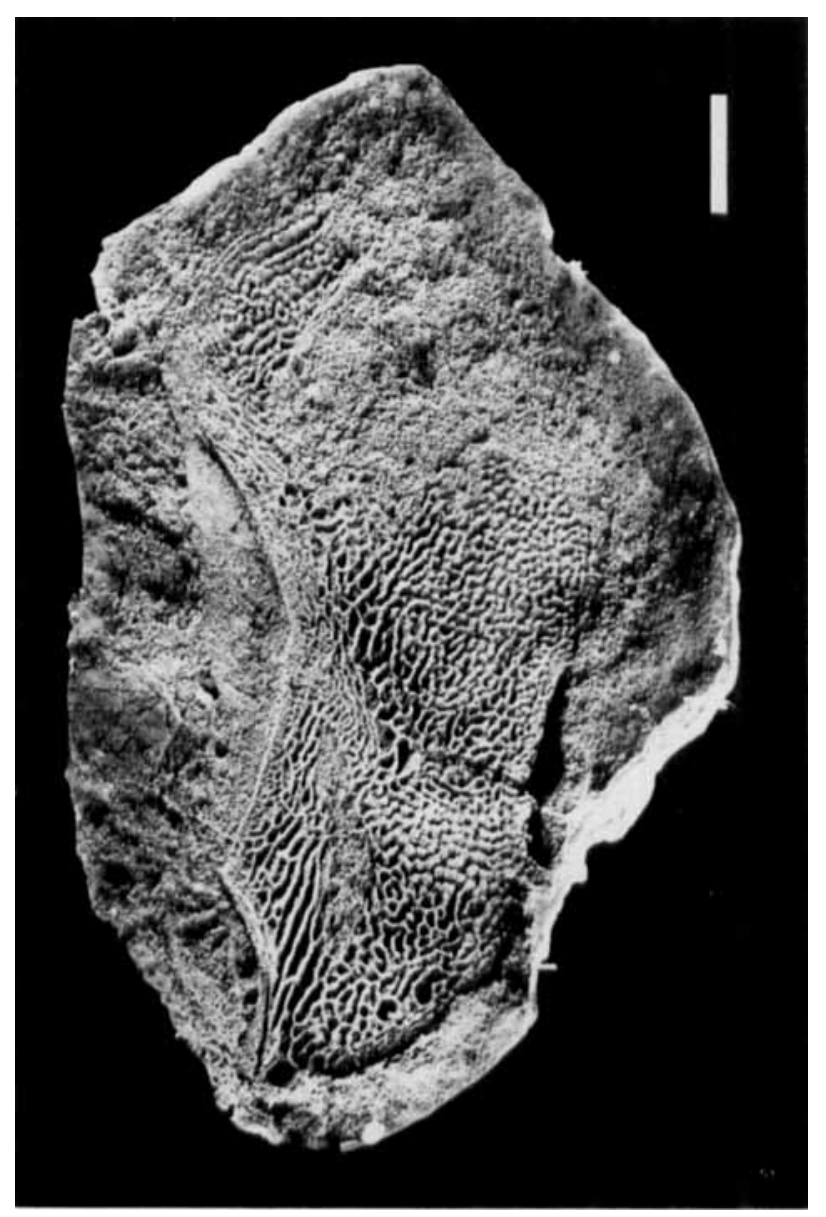

ribs or haemal arches. One centrum, just behind the posterior head shield FMNH PF14909, is seen in lateral view (Fig. 16). It exposes a neural arch. Comparable ring centra, but undeformed, occur at the Brew locality. One of which is as large $(20 \mathrm{~mm}$ diameter inside and $31 \mathrm{~mm}$ diameter outside) as the largest centrum of Litoptychus. The other twelve are smaller $(8-19 \mathrm{~mm}$ diameter inside and $12-23 \mathrm{~mm}$ diameter outside with 3-8 mm length). Centrum KUVP 124469 is thicker than all others $(7 \mathrm{~mm}$ diameter inside and $16 \mathrm{~mm}$ diameter outside) and has two stout ventral processes for the attachment of ribs.

These centra are comparable to those of Megalichthys (Andrews \& Westoll 1970: pl. 3: H).

Scales: Denison (1951) assigned round scales to Litoptychus that are reinterpreted here as either holoptychiid (Ørvig 1957) or dipnoan scales. It is more likely that the rhombic scales (after Denison 1951: scales of Osteolepididae) belong to Litoptychus, based on their similarity

Fig. 15. Litoptychus bryanti. Upper Devonian, Brew locality, Colorado. Left cleithrum KUVP 124452, in external view. Scale represents $1 \mathrm{~cm}$ 


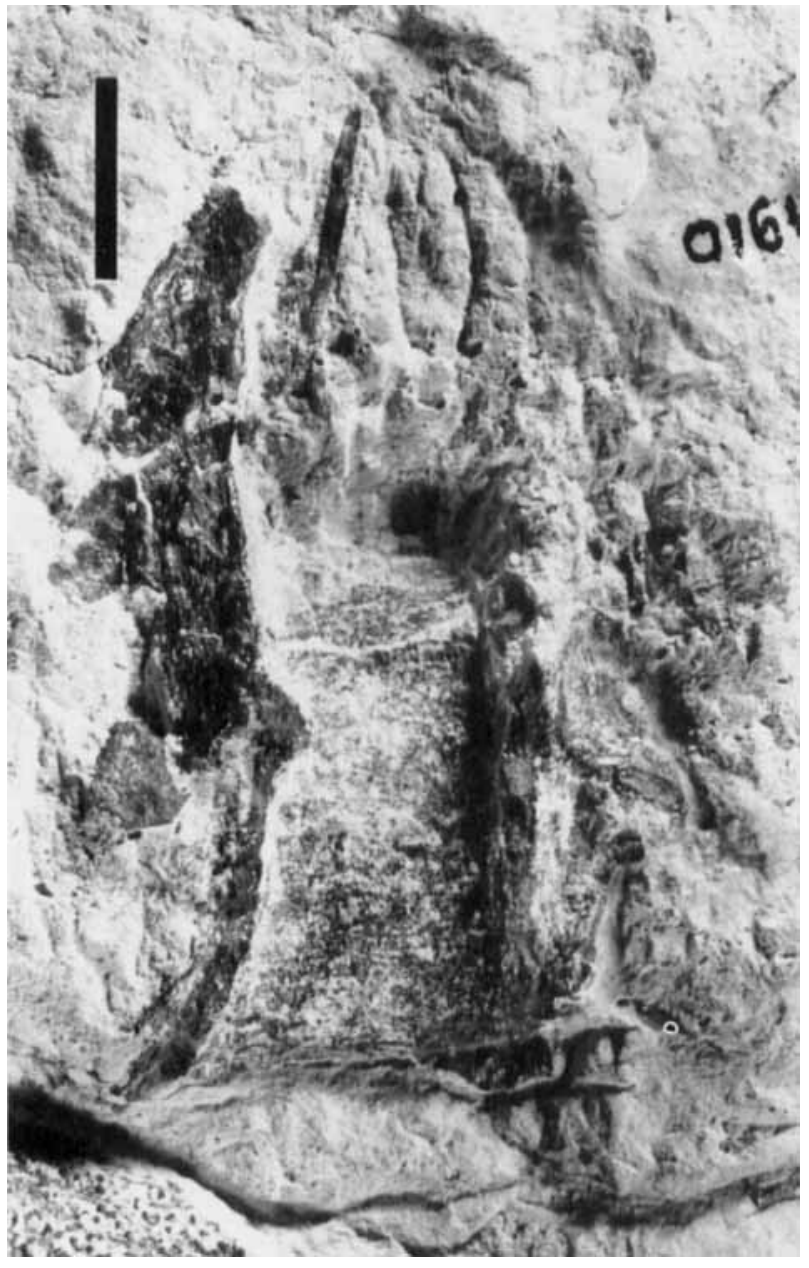

Fig. 16. Litoptychus bryanti. Upper Devonian, Deadman's Gulch, Colorado. Centrum FMNH PF14909, in lateral view. Scale represents $1 \mathrm{~cm}$

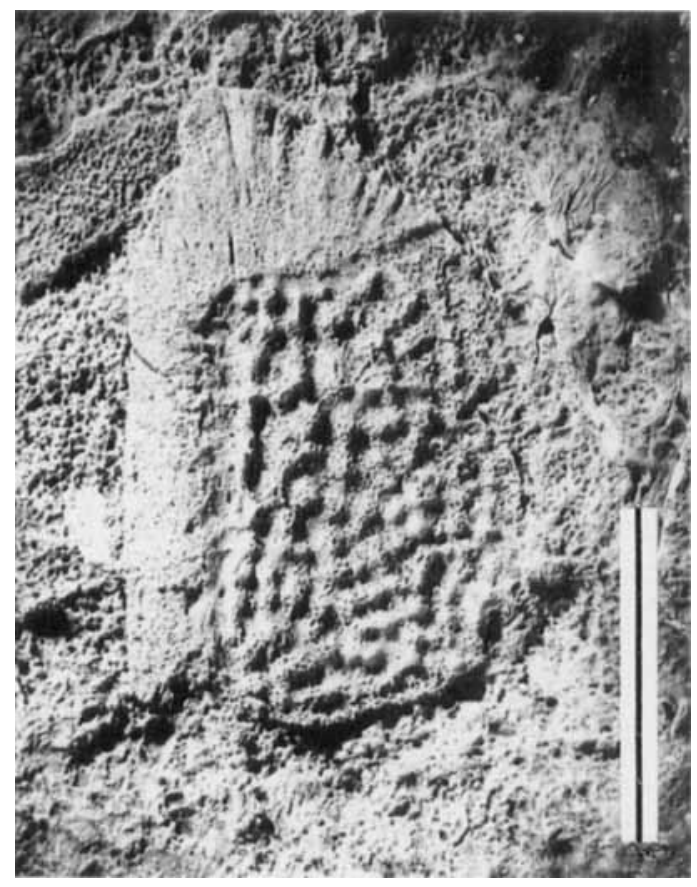

Fig. 17. Litoptychus bryanti. Upper Devonian, Brew locality, Colorado. Scale KUVP 124495, in external view. Scale represents $1 \mathrm{~cm}$ with those of Glyptopomus and their association with the skull KUVP 124448 from the Brew locality. The ornament of the rhombic scales (Fig. 17) corresponds to the ornament of the skull bones. The free exposed field with its tuberculation (Denison 1951: fig. 47A) and sometimes with remains of cosmine (Denison 1951: fig. $47 \mathrm{C}$ ) is separated by a groove from the overlapped parts of the scale. This groove is more distinct towards the anterior margin.

\section{Comparison}

Litoptychus was placed by Denison (1951) within Rhizodontidae, by Ørvig (1957) within Holoptychiidae, by Jessen (1967) within Osteolepididae and by Schultze (1969) close to Eusthenodon and Platycephalichthys. The round scales occurring with the remains of Litoptychus, may really belong to a holoptychiid or lungfish that co-occur with Litoptychus at Deadman's Gulch. The association of round scales with Litoptychus probably accounts for Ørvig's holoptychiid identification. The rhombic scales with a tuberculate free field in the deposits at Deadman's Gulch are almost certainly those of Litoptychus. Denison's Rhizodontidae include genera that are placed today in Rhizodontida, Osteolepiformes and Elpistostegalia. He used the misinterpreted tooth structure, dentary fang and ornamentation of round scales to distinguish Litoptychus from Eusthenopteron, Tristichopterus, Sauripterus, Rhizodus and Strepsodus. He placed the co-occurring rhombic scales within Osteolepididae. The structure of the lower jaw (general shape and presence of adsymphysial tooth plate) are osteolepidid features (Jessen 1967). The tooth structure of Litoptychus is eusthenodont (Schultze 1969: 118). Litoptychus and Eusthenodon, and many other osteolepiforms, have a similarly shaped postparietal, narrow anteriorly and broad posteriorly. Similarity with many Osteolepididae, e.g. Glyptopomus, is even closer (Fig. 18), having a broad and long posterior portion of the postparietal. In contrast to Eusthenodon (and also Tristichopteridae) but in agreement with Glyptopomus (and other Osteolepididae, Jarvik 1948: tab. 1) is the relation between anterior and posterior head shield (about 1:1) and between cheek plate and posterior head shield (more than 2:1). Both Litoptychus and Glyptopomus (and many Osteolepididae) possess an extratemporal that is missing in Eusthenodon (and all Tristichopteridae). The preoperculum is narrow 


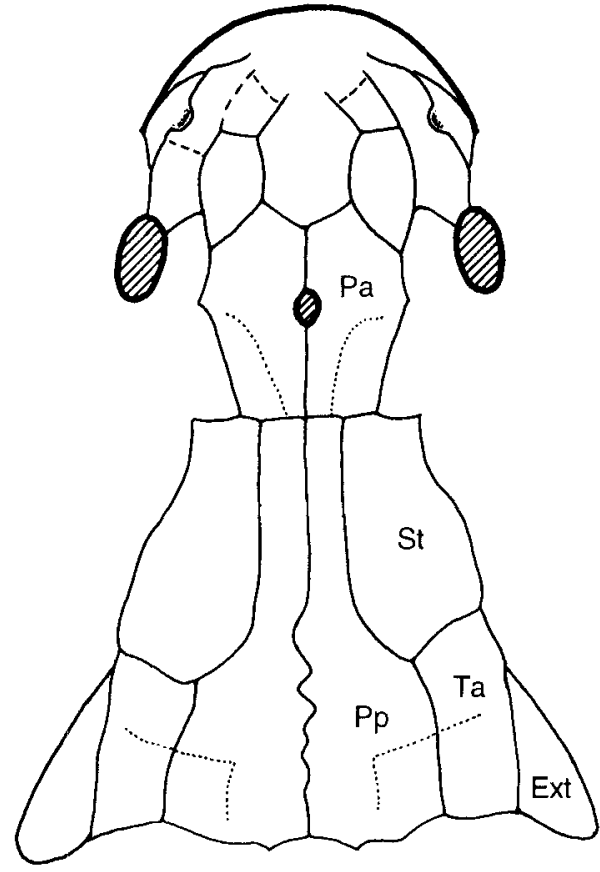

A

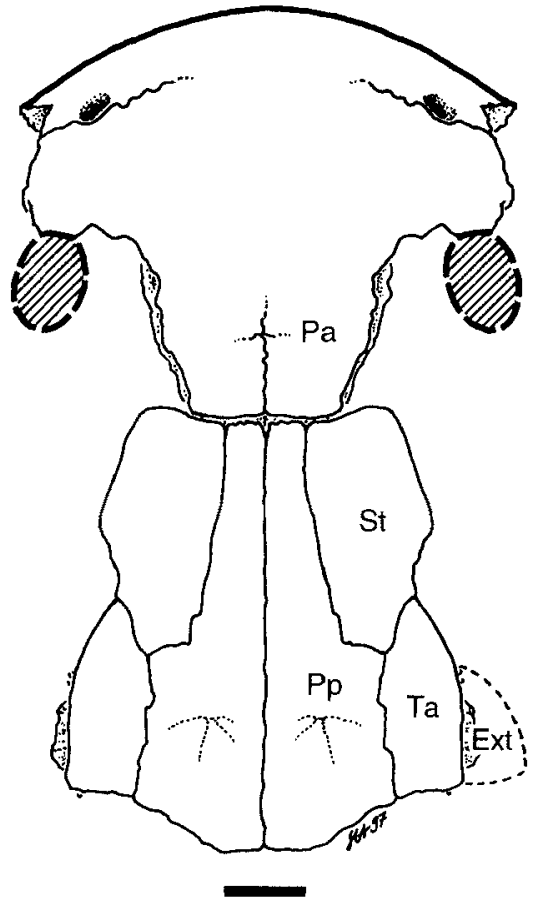

B

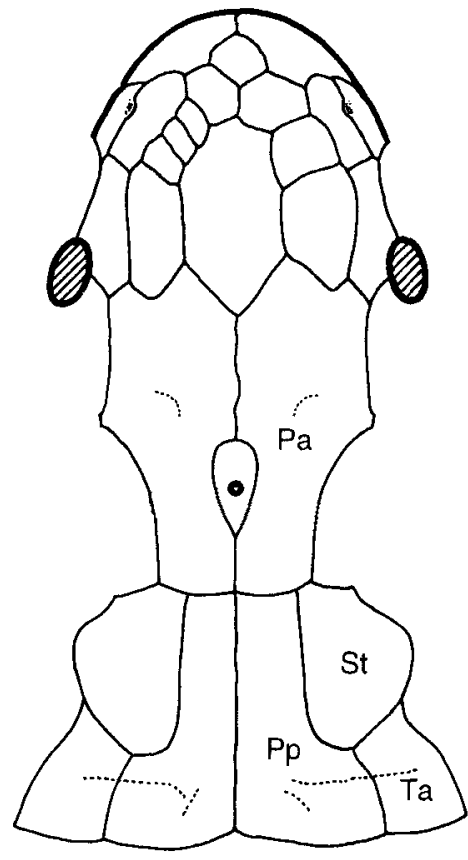

C

Fig. 18. Comparison of the skull roof in dorsal view of $\mathbf{B}$, Litoptychus bryanti with that of A, Glyptopomus kinnairdi (Huxley, 1859) (after Jarvik 1950: fig. 5B) and C, Eusthenodon waengsjoei Jarvik, 1952 (after Jarvik 1952: fig. 26B). Ext, extratemporal; $\mathbf{P a}$, parietal; Pp, postparietal; $\mathbf{S t}$, supratemporal; Ta, tabular

in Litoptychus and Glyptopomus (as in other Osteolepididae) whereas it is broad in Eusthenodon; the jugal is larger than the postorbital in Litoptychus and Glyptopomus in contrast to Eusthenodon, other Tristichopteridae and Osteolepididae. Litoptychus has in common with Eusthenodon the eusthenodont tooth structure (also in Platycephalichthys nevertheless distribution of the feature unknown) and a fang on the anterior dentary. The latter feature is known in advanced Tristichopteridae (Ahlberg \& Johanson 1997), Megalichthyidae (Fox et al. 1995), Rhizodontida (Young et al. 1992) and Panderichthys (Gross 1941), but unknown in Osteolepididae.

The comparison with Eusthenodon, an advanced tristichopterid (= eusthenopterid; Ahlberg \& Johanson 1997), and with Glyptopomus, an osteolepidid without a cosmine cover, places Litoptychus within the primitive and possibly paraphyletic Osteolepididae (Long 1985). Litoptychus lacks advanced features that would place the genus within Tristichopteridae. Litoptychus may be close to Glyptopomus sayrei from the Upper Devonian of Colorado, a comparison denied by Denison (1951). Unfortunately, Glyptopomus sayrei is only known by the ventral side of the anterior body (Newberry 1889: pl. 18:1) so that only the gulars can be compared.
Litoptychus is characterized by a fang on the anterior dentary, an anterior head shield without visible sutures and without pineal opening, a long postorbital portion of the palatoquadrate and many cheek characters (squamosal forming most of cheek, small postorbital and jugal, large quadratojugal separating the narrow vertical preoperculum for most of its length from the squamosal). Consequently Litoptychus is a well defined genus within Osteolepididae.

\section{Indet.}

\section{Material}

Deadman's Gulch: Bones: FMNH PF612 (large operculum), PF616 (coronoids with tooth), PF618 (bone, ?cleithrum), PF619 (many pieces).

Boulder Lake: Impression of scales: FMNH PF584, PF586.

Brew locality: Bones: KUVP 124451, 124453, 124456, $124459,124462,124464,124472,124475,124477,124479$, $124480,124483,124494,124496,124497,124499,124515$, $124526,124529,124530,124531,124538,124539,124540$, $124543,124544,124546,124552,124557,124560,124561$, 124978 .

Here, for completeness, material is listed that could not be placed within any of the groups de- 
scribed in the paper. Identification is difficult because the surface ornamentation (coarse tuberculation) of bones of these groups is so similar.

\section{Paleogeography and Paleoecology}

Denison (1951) reported, what he supposed were freshwater fishes, Bothriolepis and Holoptychius were "everywhere characteristic of the continental 'Old Red Sandstone' type of deposits" (p. 255). Though he admitted that "As far as the geological evidence goes, all could be littoral marine fishes, ..." (p. 255). He solved the contradiction by proposing that these genera "were inhabitants of fresh-water streams and were washed after death into the edges of the advancing Chemung sea" (p. 256).

The Elbert Formation (Fig. 1) is the eastern and northeastern equivalent of the marine Martin (Chino and Verde Valley, Arizona) and Temple Butte (Grand Canyon, Arizona) formations (Beus 1980). Denison (1951: fig. 49) gave a correct paleogeographic distribution of the Late Devonian sea (compare Baars 1972: fig. 6). The sandstones at the Brew and other localities in Colorado represent transgressive facies of that sea close to shallow areas associated with rises of Precambrian rocks. A similar paleogeographic occurrence of Bothriolepis and rises of Precambrian rocks is found in the Temple Butte Formation in Arizona, whereas the fully marine fish fauna of Mount Elbert occurs away from the coast line or rises of the sea bottom.

Bothriolepis and Holoptychius no longer can be taken as indicators of continental or freshwater deposits. They are known in marine deposits. In addition, faunal comparisons do not justify their use as freshwater indicators (Schultze \& Cloutier 1996). To the contrary, Bothriolepis canadensis, earlier considered to be a freshwater inhabitant, is now thought to have been marine based on $\mathrm{Sr}^{87} / \mathrm{Sr}^{86}$ isotope studies (Schmitz et al. 1991). The marine occurrence of B. canadensis is supported for the Frasnian locality of Miguasha, where it co-occurs with marine indicators (acritarchs, Cloutier et al. 1997, and trace fossils, Maples 1996). Geochemical studies of the sediments of the Miguasha deposits are also consistent with a brackish to marine depositional environment. Tolerance of marine conditions also most reasonably explains the nearly ubiquitous distribution of Bothriolepis worldwide and its occurrence in the marine Upper Devonian deposits of Gogo, Western Australia (Young 1984). Denison (1951:
Table 2. Comparison of Frasnian fish faunas in Colorado and Arizona

\begin{tabular}{|c|c|c|c|}
\hline & $\begin{array}{l}\text { Parting } \\
\text { Member/ } \\
\text { Central } \\
\text { Colorado }\end{array}$ & $\begin{array}{l}\text { Elbert } \\
\text { Formation/ } \\
\text { SW Colo- } \\
\text { rado }\end{array}$ & $\begin{array}{l}\text { Martin } \\
\text { Formation/ } \\
\text { Arizona }\end{array}$ \\
\hline $\begin{array}{l}\text { Bothriolepis } \\
\quad \text { coloradensis } \\
\text { sp. }\end{array}$ & $x$ & $x$ & $x$ \\
\hline $\begin{array}{l}\text { Eldenosteus } \\
\quad \text { arizonensis }\end{array}$ & & & $x$ \\
\hline $\begin{array}{l}\text { Holonema } \\
\text { sp. }\end{array}$ & & & $x$ \\
\hline Dinichthyids A, B & & & $x$ \\
\hline Arthrodira A, B, C & & $?$ & $x$ \\
\hline $\begin{array}{l}\text { Ptyctodus } \\
\text { bradyi }\end{array}$ & & & $x$ \\
\hline $\begin{array}{l}\text { Denisonodus } \\
\text { plutonensis }\end{array}$ & & & $x$ \\
\hline bradyodont & & $x$ & \\
\hline $\begin{array}{l}\text { Dipterus } \\
\quad \text { mordax } \\
\text { sp. }\end{array}$ & $x$ & $x$ & $x$ \\
\hline $\begin{array}{l}\text { Onychodus } \\
\text { sp. }\end{array}$ & $x$ & $x$ & $x$ \\
\hline $\begin{array}{l}\text { Holoptychius } \\
\text { sp. }\end{array}$ & $x$ & $x$ & $x$ \\
\hline $\begin{array}{l}\text { Litoptychus } \\
\text { bryanti }\end{array}$ & $x$ & $x$ & \\
\hline Osteolepidid indet. & $x$ & $x$ & \\
\hline
\end{tabular}

222) excluded the marine fishes of the Martin Formation from comparison. Johnson \& Elliott (1995, 1996) gave a faunal list of the marine Martin Formation that includes Bothriolepis, ?Holoptychius, Onychodus and dipnoans, forms that also occur in the Elbert Formation (Tab. 2). Bothriolepis was also recorded from the marine Temple Butte Formation (Noble 1922). Johnson \& Elliott (1995) recorded a number of typical marine arthrodires from the Martin Formation that are missing in the Elbert Formation. These typical marine arthrodires and their accompanying fish fauna occur on the carbonate shelf whereas all other, more impoverished fish faunas, are found close to rises of Precambrian rocks, which may indicate coastal areas.

In conclusion, geological and faunal evidence point to a coastal marine environment for the fishes of the Elbert Formation, which is supported by the transition of the Elbert Formation into the full marine Temple Butte and Martin formations. 


\section{Acknowledgments}

We are indebted to Dr. D. K. Elliott, Northern Arizona University, Flagstaff, Arizona, who kindly informed us of the discovery of Late Devonian fishes north of Vallecito Reservoir by Dr. D. Brew, Fort Lewis College, Durango, Colorado. Dr. Brew taught geological mapping courses in the area. He and Nina Voreggen kindly accomodated us in Durango and guided as to the locality in a wilderness area. We thank the U.S. Forest Service for permission to collect.

We thank O. Bonner, Natural History Museum, Lawrence, for preparing the latex casts, L. Berner, Museum für Naturkunde, Berlin, for preparing the specimens FMNH PF1490314917 on blocks FMNH PF615 and PF619 and Elke Siebert, Museum für Naturkunde, Berlin, for drawing the figures. The senior author thanks Dr. L. Grande, Field Museum of Natural History, Chicago, for permission to study the Denison collections of Late Devonian fishes from southwestern and central Colorado. Dr. D. K. Elliott, Flagstaff, Arizona, and Dr. J.A. Clack, Cambridge, kindly reviewed the manuscript.

\section{References}

Ahlberg, P. E. \& Johanson, Z. 1997. Second tristichopterid (Sarcopterygii, Osteolepiformes) from the Upper Devonian of Canowindra, New South Wales, Australia, and phylogeny of the Tristichopteridae. - Journal of Vertebrate Paleontology 17 (4): 653-673.

Andrews, S. M. 1972. The shoulder girdle of 'Eogyrinus'. In Joysey, K.A. \& Kemp, T.S. (eds.), Studies in Vertebrate Evolution. Essays presented to Dr. F.R. Parrington, FRS: 35-48. Edinburgh (Oliver and Boyd)

Andrews, S. M. \& Westoll, T. S. 1970. The postcranial skeleton of rhipidistian fishes excluding Eusthenopteron. The Royal Society of Edinburgh, Transactions 68 (12): $391-489$.

Baars, D. L. 1972. Devonian system. In Mallory, W. W. et al. (eds.), Geologic Atlas of the Rocky Mountain Region. Rocky Mountain Association of Geologists: 90-99. Denver (A.B. Hirschfeld Press).

Beus, S. S. 1980. Late Devonian (Frasnian) paleogeography and paleoenvironments in northern Arizona. In Fouch, T.D. \& Magathan, E.R. (eds.), Paleozoic paleogeography of West-Central United States. Rocky Mountain Paleogeography Symposium 1: 55-69.

Bryant, W. L. \& Johnson, J. H. 1936. Upper Devonian fish from Colorado. - Journal of Paleontology $10(7)$ : $650-659$.

Campbell, K. S. W. \& Barwick, R. E. 1987. Palaeozoic Lungfishes - A Review. In Bemis, W.E., Burggren, W.W. \& Kemp, N.E. (eds.), The Biology and Evolution of Lungfishes. Journal of Morphology, Supplement 1: 93-131.

Campbell, K. S. W. \& Bell, M. W. 1982. Soederberghia (Dipnoi) from the Late Devonian of New South Wales. - A1cheringa 6: 143-149.

Carroll, R. L. 1987. Vertebrate Paleontology and Evolution: XIV +698 pp. New York (W.H. Freeman and Company).

Cloutier, R., Loboziak, S., Candilier, A.-M. \& Blieck, A. 1997. Biostratigraphy of the Upper Devonian Escuminac Formation, eastern Québec, Canada: a comparative study based on miospores and fishes. - Review of Palaeobotany and Palynology 93: 191-215.

Cross, W. 1904 A new Devonian formation in Colorado. American Journal of Science (4. series) 18 (106): $245-252$.

Denison, R. H. 1951. Late Devonian fresh-water fishes from the Western United States. - Fieldiana: Geology 11(5): 219-261.

Eastman, C. R. 1904. On Upper Devonian fish remains from Colorado - American Journal of Science (4. series) 18(106): 253-260.
- 1915. Dipterus remains from the Upper Devonian of Colorado. - Annals of the Carnegie Museum 9: 279-283.

Endlich, F. M. 1876. [On the geology of the San Juan mining district]. Annual Report of the United States Geological and Geographical Survey of the Territories, embracing Colorado and parts of adjacent Territories; being a report of progress of the exploration for the year 1874: $181-240$.

Fox, R. C., Campbell, K. S. W., Barwick, R. E. \& Long, J. A. 1995. A new osteolepiform fish from the Lower Carboniferous Raymond Formation, Drummond Basin, Queensland. - Memoirs of the Queensland Museum 38: 97-221.

Gross, W. 1941. Über den Unterkiefer einiger devonischer Crossopterygier. - Abhandlungen der preußischen Akademie der Wissenschaften, Mathematisch-Naturwissenschaftliche Klasse 1941: 1-51.

Jarvik, E. 1944. On the exoskeletal shoulder-girdle of teleostomian fishes, with special reference to Eusthenopteron foordi Whiteaves. - Kungliga svenska Vetenskaps Akademiens Handlingar (3. Serien) 21 (7): 1-32.

- 1948. On the morphology and taxonomy of the Middle Devonian osteolepid fishes of Scotland. - Kungliga svenska Vetenskaps Akademiens Handlingar (3. Serien) 25 (1): 1-301.

1950. On some osteolepiform crossopterygians from the Upper Old Red Sandstone of Scotland. - Kungliga svenska Vetenskaps Akademiens Handlingar (4. Serien) 2 (2): $1-35$.

- 1952. On the fish-like tail in the ichthyostegid stegocephalians with descriptions of a new stegocephalian and a new crossopterygian from the Upper Devonian of East Greenland. - Meddelelser om Grønland 114 (12): 1-90.

- 1954. On the visceral skeleton in Eusthenopteron with a discussion of the parasphenoid and palatoquadrate in fishes. - Kungliga svenska Vetenskaps Akademiens Handlingar (4. Serien) 5: 1-104.

- 1980. Basic Structure and Evolution of Vertebrates. Volume 1: XVI + 575 pp. London, New York (Academic Press)

Jessen, H. 1967. Die Crossopterygier des Oberen Plattenkalkes (Devon) der Bergisch-Gladbach-Paffrather Mulde (Rheinisches Schiefergebirge) unter Berücksichtigung von amerikanischem und europäischem Onychodus-Material. - Arkiv för Zoologi (Serie 2) 18 (14): 305-389.

Johnson, H. G. \& Elliott, D. K. 1995. A redescription of Eldenosteus arizonensis (Placodermi: Arthrodira) from the Upper Devonian Martin Formation of Northern Arizona. - Journal of Vertebrate Paleontology 15(2): 221-234.

- 1996. A new ptyctodont (Placodermi) from the Upper Devonian Martin Formation of Northern Arizona, and an analysis of ptyctodont phylogeny. - Journal of Paleontology 70(6): 994-1003.

Lebedev, O. A. 1995. A new osteolepid fish from Russia. Bulletin de la Muséum national d'Histoire naturelle, Paris (4. série) 17 (section C: Sciences de la Terre): 287-341.

Lehman, J.-P. 1959. Les dipneustes du Dévonien supérieur $\mathrm{du}$ Groenland. - Meddelelser om Grønland 160 (4): $1-58$.

- 1966. Crossopterygii. In Piveteau, J. (ed.), Traité de Paléontologie IV (3): 301-387, 398-412. Paris (Masson et Cie.).

Long, J. A. 1985. A new osteolepidid fish from the Upper Devonian Gogo Formation, Western Australia. - Records of the Western Australian Museum 12: 361-377.

- 1987. An unusual osteolepiform fish from the Late Devonian of Victoria, Australia. - Palaontology 30: 839-852.

Long, J. A., Barwick, R. E. \& Campbell, K. S. W. 1997. Osteology and functional morphology of the osteolepiform fish Gogonasus andrewsae Long, 1985, from the Upper Devonian Gogo Formation, Western Australia. - Records of the Western Australian Museum, Supplement 53: $1-89$. 
Maples, C. G. 1996. Paleoenvironmental significance of trace fossils in the Escuminac Formation. In Schultze, H.-P. \& Clouticr, R. (eds.), Devonian fishes and plants of Miguasha, Quebec, Canada: 114-119. München (Dr. Friedrich Pfeil).

Newberry, J . S. 1889. The Paleozoic Fishes of North America. - Monographs of the United States Geological Survey 16: $1-228$.

Noble, L. F. 1922. A section of the Paleozoic formations of the Grand Canyon at the Bass trail. - U.S. Geological Survey Professional Paper 131: 23-73.

Ørvig, T. 1957. Remarks on the vertebrate fauna of the lower Upper Devonian of Escuminac Bay, P.Q., Canada, with special reference to the porolepiform crossopterygians. - Arkiv för Zoologi, ser. 2, 10(6): 367-397.

Romer, A. S. 1966. Vertebrate paleontology. 3. ed.: IX + $468 \mathrm{pp}$. Chicago, London (The University of Chicago Press).

Schmitz, B., Åberg, G., Werdelin, L., Forey, P. \& BendixAlmgreen, E. $1991 .{ }^{87} \mathrm{Sr}{ }^{86} \mathrm{Sr}, \mathrm{Na}, \mathrm{F}, \mathrm{Sr}$, and La in skeletal fish debris as a measure of the paleosalinity of fossil-fish habitats. - Geological Society of America, Bulletin 103: $786-794$.

Schultze, H.-P. 1969. Die Faltenzähne der rhipidistiiden Crossopterygier, der Tetrapoden und der ActinopterygierGattung Lepisosteus. - Palaeontographia Italica 65: $60-137$.
Schultze, H.-P. \& Chorn, J. 1997. The Permo-Carboniferous genus Sagenodus and the beginning of modern lungfish. - Contributions to Zoology 67 (1): 9-70.

Schultze, H.-P. \& Cloutier, R. 1996. Comparison of the Escuminac Formation ichthyofauna with other late Givetian/ early Frasnian ichthyofaunas. In Schultze, H.-P. \& Cloutier, R. (eds.), Devonian fishes and plants of Miguasha, Quebec, Canada: 348-368. München (Dr. Friedrich Pfeil).

Stensiö, E. A:son. 1931. Upper Devonian verterates from East Greenland, collected by the Danish Greenland expedition in 1929 and 1930. - Meddelelser om Grønland 86: $1-212$.

- 1948. On the Placodermi of the Upper Devonian od East Greenland. II. Antiarchi: subfamily Bothriolepinae. Meddelelser om Grønland 139: 1-633.

Vorobyeva, E. I. \& Obruchev, D .V. 1964. Subclass Sarcopterygii. In Obruchev, D.V. (ed.), Osnovy paleontologii. Vol. XI. Agnatha, Pisces: 268-322. Moskva (Izdatel'stvo 'Nauka').

Young, G. C. 1984. Reconstruction of the jaws and braincase in the Devonian placoderm fish Bothriolepis. - Palaeontology 27: 121-131.

Young, C. G., Long, J. A. \& Ritchie, A. 1992. Crossopterygian fishes from the Devonian of Antarctica: systematics, relationships and biogeographic significance. - Records of the Australian Museum, Supplement 14: 1-77. 